\title{
Exchange Rate Uncertainty and International Portfolio Flows: A Multivariate GARCH-in-Mean Approach
}

\author{
Guglielmo Maria Caporale ${ }^{\mathrm{a}, \mathrm{b}, \mathrm{c}^{*}}$, Faek Menla Ali $^{\mathrm{a}}$ and Nicola Spagnolo ${ }^{\mathrm{a}, \mathrm{d}}$ \\ a Department of Economics and Finance, Brunel University London, UK

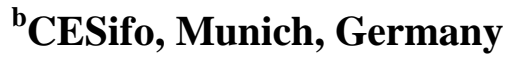 \\ ${ }^{\mathrm{C}}$ DIW Berlin, Germany \\ ${ }^{\mathrm{d}}$ Centre for Applied Macroeconomic Analysis (CAMA), Canberra, Australia
}

Revised, January 2015

\begin{abstract}
This paper examines the impact of exchange rate uncertainty on different components of net portfolio flows, namely net equity and net bond flows, as well as their dynamic linkages. Specifically, a bivariate VAR GARCHBEKK-in-mean model is estimated using bilateral monthly data for the US vis-à-vis Australia, Canada, the euro area, Japan, Sweden, and the UK over the period 1988:01-2011:12. The results indicate that the effect of exchange rate uncertainty on net equity flows is negative in the euro area, the UK and Sweden, and positive in Australia. The impact on net bond flows is also negative in all countries except Canada, where it is positive. Under the assumption of risk aversion, the findings suggest that exchange rate uncertainty induces a home bias and causes investors to reduce their financial activities to maximise returns and minimise exposure to uncertainty, this effect being stronger in the UK, the euro area and Sweden compared to Canada, Australia and Japan. Overall, the results indicate that exchange rate or credit controls on these flows can be used as a policy tool in countries with strong uncertainty effects to pursue economic and financial stability.
\end{abstract}

Keywords: Exchange rate uncertainty, Equity flows, Bond flows, Causality-in-variance JEL Classification: F31, F32, G15

\footnotetext{
*Corresponding author. Email addresses: Guglielmo-Maria.Caporale@brunel.ac.uk (G.M. Caporale), Faek.MenlaAli@brunel.ac.uk (F. Menla Ali), Nicola.Spagnolo@brunel.ac.uk (N. Spagnolo).

We would like to thank for their valuable suggestions and comments the editor and two anonymous referees, as well as Kate Phylaktis, Jerry Coakley, Tomoe Moore, Dick van Dijk, Peter Boswijk, and participants in the $9^{\text {th }}$ BMRC-QASS Conference on Macro and Financial Economics, May 30 ${ }^{\text {th }}, 2013$, Brunel University London, UK, the $12^{\text {th }}$ INFINITI Conference on International Finance, June 9-10 ${ }^{\text {th }}$, 2014, Monash University Prato Centre, Prato, Italy, the International Association for Applied Econometrics Annual Conference, June 26-28 ${ }^{\text {th }}$, 2014, Queen Mary, University of London, UK, as well as seminars at LUISS, Rome, 21 May 2014, and the Economics Department, University of Warwick, 23 November 2014.
} 


\section{Introduction}

The macroeconomic effects of exchange rate uncertainty, especially on trade flows, have received considerable attention since the collapse of the Bretton Woods system in 1971 and the adoption of floating exchange rates in March 1973, both in the theoretical and empirical literature (see McKenzie, 1999, for a comprehensive review). By contrast, such effects on financing activities, in particular on equity and bond portfolio flows, have not been thoroughly examined.

In addition, there is a substantial literature examining the determinants of international asset transactions, but there are very few empirical papers analysing the impact of exchange rate uncertainty. For example, Bohn and Tesar (1996) found that investors tend to move to markets where returns are expected to be high. The validity of this 'return chasing' hypothesis has been confirmed by Bekaert et al. (2002), who found that positive return shocks lead to an increase in short-term equity capital flows using data from 20 emerging countries. Portes et al. (2001) and Portes and Rey (2005), by contrast, showed that financial transactions are explained by the gravity model at least as well as goods trade. More recently, Fratzscher (2012) found evidence that push factors were important drivers of net capital flows during the recent financial crisis, but not during the recovery period (2009-2010), when domestic pull factors were dominant, especially for emerging countries in Asia and Latin America.

The underlying idea is that exchange rate volatility increases the costs of international financial transactions and reduces potential gains from international diversification by making the acquisition of foreign securities such as bonds and equities more risky, which in turn affects negatively portfolio flows across borders. Indeed, Eun and Resnick (1988) had previously shown that exchange rate risk is non-diversifiable and has an adverse impact on the performance of international portfolios. This finding is also consistent with the evidence presented in the study by Levich et al. (1999), who found, by surveying 298 US institutional 
investors, that foreign exchange risk hedging constitutes only $8 \%$ of total foreign equity investment. Further, Choi and Rajan (1997) reported that foreign exchange risk has a significant effect on asset returns in seven major developed countries other than the US, and that ignoring such a factor results in misspecification when analysing the integration or segmentation of international capital markets. By considering a wide range of developed and emerging market economies, Fidora et al. (2007) and Borensztein and Loungani (2011) also found that exchange rate volatility is an essential factor for bilateral equity and bond portfolio home bias.

Eun and Resnick (1988) suggested that hedging through forward exchange contracts and multicurrency diversification are effective ways to reduce exchange rate risk. Glen and Jorion (1993) and Eun and Resnick (1994) provided further evidence that hedging in the forward exchange markets improves the performance of diversified portfolios of equities and bonds. Jorion (1991) also found that the exchange rate risk is diversifiable. In particular, his empirical findings provided little evidence that US investors require compensation for bearing the exchange rate risk. Gehrig (1993), instead, argued that exchange rate risk, purchasing power risk, and capital market restrictions are insufficient factors for explaining equity portfolio home bias, whilst informational segmentation plays a key role.

Finally, Hau and Rey (2006) provided a theoretical framework for analysing the implications of incomplete foreign exchange risk trading for the correlation structure of exchange rate changes and equity returns, as well as exchange rate changes and net portfolio flows; ${ }^{1}$ however, they did not carry out any statistical tests for the impact of exchange rate uncertainty on portfolio flows across borders.

\footnotetext{
${ }^{1}$ Their analysis was motivated by the recent microstructure approach to exchange rate determination which has been shown to improve remarkably the performance of exchange rate models, with currency order flows explaining a substantial proportion of exchange rate changes (see, e.g., Evans and Lyons, 2002; 2005; 2008; Payne, 2003; Rime et al., 2010; Chinn and Moore, 2011; Duffuor et al., 2012, among others).
} 
The present paper makes a fourfold contribution to the existing literature. First, it analyses empirically whether exchange rate uncertainty affects international portfolio flows and their variability using a bivariate VAR GARCH $(1,1)$-in-mean framework. It is in fact the first empirical investigation of this kind, based on bilateral monthly data for the US vis-àvis six developed economies, namely Australia, Canada, the euro area, Japan, Sweden, and the UK over the period 1988:01-2011:12. The analysis is based on longer monthly time series and differs from previous studies which focus on the determinants of home bias and international financial transactions using panel and cross-sectional techniques (see, for examples, Portes and Rey, 2005; Fidora et al., 2007; Bekaert and Wang, 2009; Batten and Vo, 2010; Borensztein and Loungani, 2011; Mishra, 2011; Mercado, 2013; Daly and Vo, 2013). We use the most common time series measure of uncertainty found in the literature, i.e. the conditional variance modelled as a $\operatorname{GARCH}(1,1)$ process $^{2}$ (others are the continuous volatility measure in Portes and Rey (2005), the stochastic deviation from purchasing power parity (PPP) in Fidora et al. (2007) and Mishra (2011), the standard deviation of exchange rate changes in Bekaert and Wang (2009) and the coefficient of variation of the real exchange rate in Mercado (2013)). This approach is flexible enough to allow for joint estimation of the relationship between uncertainty and portfolio flows taking into account past information on perceived uncertainty. $^{3}$

Second, unlike Hau and Rey (2006), who assumed that the supply of bonds is infinitely elastic, thereby simplifying the dynamics of bond acquisitions in their model, we examine the impact of exchange rate uncertainty on the individual components of portfolio flows across borders, i.e. on net bond and equity flows (as well as their variability) in turn. According to Hau and Rey (2006), exchange rate uncertainty should affect equity, but not

\footnotetext{
${ }^{2}$ Studies adopting this measure of perceived risk or uncertainty include Kroner and Lastrapes, 1993; Grier et al., 2004; Elder and Serletis, 2010; Rahman and Serletis, 2012; and Grier and Smallwood, 2013 among others.

${ }^{3}$ See also Kroner and Lastrapes (1993).
} 
bond flows. Fidora et al. (2007) and Borensztein and Loungani (2011), by contrast, found evidence that bond flows exhibit stronger home bias compared to equity flows. We provide some relevant empirical evidence on this issue.

Third, existing empirical studies on the relationship between exchange rate changes and portfolio flows investigate short-run dynamic interactions only with linear dependence techniques (i.e., first moment analysis). For example, Brooks et al. (2004) and Hau and Rey (2006) use simple correlations and regression analysis for the US vis-à-vis the euro area and Japan, and 17 OECD countries, respectively; Siourounis (2004), Chaban (2009), and Kodong and Ojah (2012) estimate VAR models respectively for four developed countries (the UK, Japan, Germany, and Switzerland), three commodity-exporting countries (Canada, Australia, and New Zealand), and four African countries (Egypt, Morocco, Nigeria, and South Africa) vis-à-vis the US. Their results are characterised by significant deviations from normality and conditional heteroscedasticity, i.e., volatility clustering or so-called ARCH effects (see Engle, 1982) that are not captured by their setup. By contrast, we model the first and second moments simultaneously to analyse the dynamic interactions between exchange rate changes and portfolio flows. In this way, we capture the volatility in the flows and exchange rate changes which is well documented in the economics and finance literature, and address some of the potential pitfalls of earlier studies.

Fourth, since volatility is a measure of the information flow (see Ross, 1989), it is of paramount importance to understand how the stochastic information arrivals in the form of simple portfolio investment shifts in bonds and equities are transmitted to the foreign exchange market, and vice versa. Furthermore, knowledge of the response of investors to exchange rate uncertainty provides important information to policy-makers and regulators to formulate appropriate policies based on imposing or relaxing credit controls on these flows depending on the state of the economy, with the aim of achieving economic and financial stability. For example, if exchange rate uncertainty dampens net inflows, expansionary 
policies to boost the economy during recessionary periods could be unsuccessful if exchange rates are too volatile. In such circumstances, credit controls on inflows may be relaxed, and such a policy is likely to increase inflows, thereby boosting the economy. In addition, financial and economic stability can be pursued by reducing exchange rate volatility.

The remainder of the paper is organised as follows. Section 2 describes the data and carries out some preliminary analysis. Section 3 outlines the econometric model and the hypotheses tested. Section 4 discusses the empirical results, and finally Section 5 concludes.

\section{Data description and preliminary analysis}

We examine the impact of exchange rate uncertainty on different components of net portfolio flows, namely net equity and net bond flows, as well as their dynamic linkages for the US vis-à-vis Australia, Canada, the euro area, Japan, Sweden, and the UK. Throughout, the US is considered the domestic or home economy. The data on portfolio investment flows, obtained from the US Treasury International Capital (TIC) System, ${ }^{4}$ are monthly and cover the period from 1988:01 to 2011:12 for all series. The reason for selecting this start date is that cross-border portfolio flows for the period preceding 1988 are known to be negligible (see Brooks et al., 2004).

\footnotetext{
${ }^{4}$ The source is the US Treasury Department website: http//www.treasury.gov/resource-center/data-chartcenter/tic/Pages/country-longterm.aspx. As Edison and Warnock (2008) pointed out, the US TIC data have three main limitations. First, they only cover transactions that involve US residents, i.e. they include bilateral portfolio inflows and outflows vis-a-vis the US but not other cross-country portfolio flows. Second, transactions involving third countries lead to a financial centre bias in the bilateral flows data as the transaction is recorded against the foreign intermediary rather than where the issuer of the foreign security resides. Third, financing of cross-border mergers through stock swaps makes the analysis of equity flows rather difficult (for further details on the US TIC data, see Edison and Warnock, 2008). However, in spite of these limitations, the TIC data have been widely used in the empirical literature to examine bilateral portfolio flows between the US and the rest of the world.
} 
Net equity (bond) flows are calculated as equity (bond) inflows minus outflows. While inflows are measured as net purchases and sales of domestic (US) assets (equities and bonds) by foreign residents, outflows are the net purchases and sales of foreign assets (equities and bonds) by domestic residents (US). In the case of the euro area, we aggregate the data for the individual EMU countries (Austria, Belgium-Luxembourg, ${ }^{5}$ Finland, France, Germany, Ireland, Italy, the Netherlands, Portugal, and Spain) to extract cross-border bond and equity flows between the US and this region.

Positive numbers imply net equity and bond inflows (in millions of US dollars) towards the US or outflows from its counterparties. Moreover, since without scaling model convergence is difficult to achieve, we use monthly averages to adjust these flows, specifically the average of their absolute values over the previous 12 months as in Brennan and Cao (1997), Hau and Rey (2006), and Chaban (2009) among others.

Following more recent papers in the literature (e.g., Chaban, 2009; Kodongo and Ojah, 2012), the exchange rates are end-of-period data, defined as US dollars per unit of foreign currency; ${ }^{6}$ the source is the IMF’s International Financial Statistics (IFS). Exchange rate changes are calculated as $E_{t}=100 \times\left(P_{E, t} / P_{E, t-1}\right)$ where $P_{E, t}$ stands for the log of the exchange rate at time $t$. For the period preceding the introduction of the euro, i.e. before 1999, we use US dollar per ECU as the euro area's exchange rate.

Descriptive statistics are displayed in Table 1 . The mean of monthly exchange rate changes is positive (a US dollar depreciation) for Japan and Canada, and negative (a US dollar appreciation) for the rest of the countries. On the other hand, the monthly mean of net equity flows is positive for Sweden and Canada and negative for the remaining countries, indicating equity inflows from Sweden and Canada towards the US and outflows from the US towards the other countries. The monthly mean of net bond flows is negative for Australia and

\footnotetext{
${ }^{5}$ The US Treasury (our data source) reports data for both countries together for the period prior to 2000.

${ }^{6}$ We also experimented with monthly averages of exchange rates. The results were broadly the same.
} 
positive for the other countries. This indicates the existence of bond inflows from all countries except Australia (for which there is evidence of bond outflows) vis-à-vis the US.

Exchange rate changes are found to exhibit higher volatility than the two types of flows. Furthermore, equity flows appear to be characterised by higher volatility than bond flows (although their volume is very small). As for the third and fourth moments, exchange rate changes, net equity flows, and net bond flows all exhibit skewness and excess kurtosis in most cases. The Jarque-Bera (JB) test statistics imply a rejection at the $1 \%$ level of the null hypothesis that exchange rate changes and the two types of flows are normally distributed in all countries in question.

\section{[Insert Table 1 about here]}

Since we use the conditional variance (with a time-varying variance-covariance matrix) as a measure of uncertainty, we carry out Engle’s (1982) LM test for ARCH effects in the residuals of the homoscedastic VAR model of exchange rate changes and net flows to validate the use of an ARCH model in the analysis. The VAR model is specified as follows:

$$
y_{t}=\mu+\sum_{i=1}^{p} \Psi_{i} y_{t-i}+\varepsilon_{t}
$$

where $y_{t}$ is a $2 \times 1$ vector of exchange rate changes and net equity or bond flows, $\mu$ is a $2 \times 1$ vector of intercepts, $\varepsilon_{t}$ is a $2 \times 1$ vector of innovations, and $\Psi$ is a $2 \times 2$ matrix with diagonal elements capturing the response of exchange rate changes and net flows to their own lags and the off-diagonal elements representing the causality parameters between exchange rate changes and net flows. Lags are included sequentially in Equ. (1) until the residuals become free from serial correlation.

Table 2 reports the LM ARCH test statistics for the residuals of the fitted bivariate VAR model $\varepsilon_{i, t}$, where $i=1$ corresponds to exchange rate changes, and $i=2$ to net flows (equity and bond flows in turn, since the analysis is bivariate). At the $10 \%$ significance level, 
the results indicate the presence of ARCH effects up to order 6 in all variables, except for net equity flows for Australia and net bond flows for the euro area.

[Insert Table 2 about here]

\section{The econometric model}

Given the evidence of ARCH effects reported above, we employ a bivariate VARGARCH $(1,1)$ with a BEKK representation (Engle and Kroner, 1995) allowing for in-mean effects in order to examine the impact of exchange rate uncertainty on net equity and net bond flows, as well as the dynamic linkages between the first and second moments of these variables. In addition to the contemporaneous effects, various lags of exchange rate uncertainty (measured by the conditional variance) affecting the conditional mean of net equity and bond flows are included in the specification to address the potential pitfalls of models allowing only for contemporaneous interactions. The economic justification for the inclusion of such lags is that the investors' response might take some time to be incorporated into their strategies and financing activities. Therefore the conditional mean equation is specified as follows:

$$
\begin{aligned}
& y_{t}=\mu+\sum_{i=1}^{p} \Psi_{i} y_{t-i}+\sum_{i=0}^{k} \Phi_{i} h_{t-i}+\varepsilon_{t}, \\
& \mu=\left[\begin{array}{l}
\mu_{1} \\
\mu_{2}
\end{array}\right] ; \Psi_{i}=\left[\begin{array}{cc}
\psi_{11}^{(i)} & \psi_{12}^{(i)} \\
\psi_{21}^{(i)} & \psi_{22}^{(i)}
\end{array}\right] ; \Phi_{i}=\left[\begin{array}{cc}
\phi_{11}^{(i)} & \phi_{12}^{(i)} \\
\phi_{21}^{(i)} & \phi_{22}^{(i)}
\end{array}\right] ; h_{t}=\left[\begin{array}{l}
h_{11, t} \\
h_{22, t}
\end{array}\right] ; \varepsilon_{t}=\left[\begin{array}{l}
\varepsilon_{1, t} \\
\varepsilon_{2, t}
\end{array}\right]
\end{aligned}
$$

where in the $2 \times 1$ vector $y_{t}=\left[E_{t}, E F_{t}\left(B F_{t}\right)\right]^{\prime}, E_{t}$ and $E F_{t}\left(B F_{t}\right)$ indicate exchange rate changes and net equity (bond) flows, which are defined as 1 and 2, respectively. Visual inspection of 
these series (see Fig. 1 ) suggests that they follow I(0) processes. ${ }^{7}$ Therefore the level of net flows is used in the analysis, together with exchange rate changes (calculated by taking the first difference of the log exchange rate as stated earlier). $h_{t}=\left[h_{11, t}, h_{22, t}\right]^{\prime}$ is the $2 \times 1$ vector of the conditional variances, with $h_{11, t}$ and $h_{22, t}$ representing the conditional variances of exchange rate changes and net flows (equity and bond flows in turn), respectively. The parameters $\psi_{11}^{(i)}$ and $\psi_{22}^{(i)}$ measure the response of exchange rate changes and net flows to their own lags, whilst $\psi_{21}^{(i)}$ and $\psi_{12}^{(i)}$ represent mean spillovers from exchange rate changes to net flows, and vice versa ( $i$ denotes the lagged time-period). If the parameter $\phi_{21}^{(i)}$ is significantly different from zero, this implies that exchange rate uncertainty affects net equity flows and/or net bond flows (the lag length is defined in this case as $i=0,1, . ., k$, with 0 indicating the contemporaneous effect). The innovations vector is assumed to be normally distributed $\varepsilon_{t} \mid \Omega_{t-1} \sim\left(0, H_{t}\right)$ with its corresponding variance-covariance matrix given by $\left|H_{t}\right| ; \Omega_{t-1}$ is the information set available at time $t-1$. Lags of the model $(p)$ are included sequentially until serial correlation is removed by employing the Hosking (1981) multivariate $Q$-statistics on the standardised residuals $z_{s, t}=\varepsilon_{s, t} / \sqrt{h_{s, t}}$ for $s=1$, 2. We also allow for up to six lags $(k=6)$ of the conditional variances in Equ. (2). ${ }^{8}$

\footnotetext{
${ }^{7}$ This is confirmed by a battery of unit root tests; the results are available from the authors on request.

${ }^{8}$ Since the economic justification for the inclusion of such $\mathrm{k}$ lags is that the investors' response to uncertainty might take some time to be incorporated into their strategies and financing activities as stated earlier, it is likely that allowing for up to six lags $(\mathrm{k}=6)$ is sufficient to capture it.
} 
The conditional variance equation is estimated using the multivariate GARCH model in the BEKK representation of Engle and Kroner (1995). This has advantages compared to other multivariate GARCH specifications such as the VEC-GARCH model of Bollerslev et al. (1988) because of its quadratic forms ensuring that the conditional covariance matrices in the system are positive definite. ${ }^{9}$ Unlike the dynamic conditional correlation model of Engle (2002), which estimates the time-varying correlations directly, the BEKK specification allows for time-varying correlations and also for interactions between the variances in a lead-lag framework. Furthermore, the curse of dimensionality highlighted by Caporin and McAleer (2012) is not a serious issue in the present case with only two variables. The model can be represented as follows:

$$
\mathrm{H}_{t}=C^{\prime} C+A^{\prime} \varepsilon_{t-1} \varepsilon_{t-1}^{\prime} A+B^{\prime} \mathrm{H}_{t-1} B
$$

In matrix form, it can be specified as:

$$
\begin{aligned}
& {\left[\begin{array}{ll}
h_{11, t} & h_{12, t} \\
h_{21, t} & h_{22, t}
\end{array}\right]=C^{\prime} C+A^{\prime}\left[\begin{array}{cc}
\varepsilon_{1, t-1}^{2} & \varepsilon_{1, t-1} \varepsilon_{2, t-1} \\
\varepsilon_{2, t-1} \varepsilon_{1, t-1} & \varepsilon_{2, t-1}^{2}
\end{array}\right] A+B^{\prime}\left[\begin{array}{ll}
h_{11, t-1} & h_{12, t-1} \\
h_{21, t-1} & h_{22, t-1}
\end{array}\right] B,} \\
& C=\left[\begin{array}{ll}
c_{11} & 0 \\
c_{21} & c_{22}
\end{array}\right], A=\left[\begin{array}{ll}
a_{11} & a_{12} \\
a_{21} & a_{22}
\end{array}\right], B=\left[\begin{array}{ll}
b_{11} & b_{12} \\
b_{21} & b_{22}
\end{array}\right]
\end{aligned}
$$

where $C$ is constrained to be a lower triangular matrix and $A$ and $B$ are respectively ARCH and GARCH parameter matrices. Equ. (4) shows that in the BEKK specification each conditional variance and covariance in $H_{t}$ is modelled as a function of lagged conditional variances and covariances, lagged squared innovations and the cross-product of the

\footnotetext{
${ }^{9}$ For a survey on multivariate GARCH models, see Bauwens et al. (2006).
} 
innovations. Volatility is transmitted between exchange rate changes and net equity/bond flows through two channels represented by the off-diagonal parameters in the ARCH and GARCH matrices: a symmetric shock $\varepsilon_{i i, t-1}$ and the conditional variance $H_{i i, t-1}$. Volatility transmission from exchange rate changes to net equity/bond flows can be analysed by carrying out Wald tests for the null hypothesis $a_{12}=b_{12}=0$, and $a_{21}=b_{21}=0$ for volatility transmission in the opposite direction. Using Monte Carlo simulation techniques, Hafner and Hewartz (2008) showed that such causality-in-variance tests within the multivariate GARCH-BEKK models are more powerful than the cross-correlation function (CCF) two-step approach of Cheung and Ng (1996).

Given that the innovations are assumed to be normally distributed, the log likelihood function for such a model is given by:

$$
L(\theta)=\frac{-T n}{2} \ln (2 \pi)-\frac{1}{2} \sum_{t=1}^{T}\left(\ln \left|H_{t}\right|+\varepsilon_{t}^{\prime} H_{t}^{-1} \varepsilon_{t}\right)
$$

where $n$ is the number of equations, two in our case; $T$ is the number of observations, which is 287; and $\theta$ is a vector of unknown parameters to be computed. More specifically, we use the Quasi-Maximum Likelihood (QML) method of Bollerslev and Wooldridge (1992) to calculate standard errors that are robust to deviations from normality. ${ }^{10}$ As a final check of the adequacy of the estimated model we employ the Hosking (1981) multivariate Q-statistic for the squared standardised residuals to evaluate whether or not the ARCH and GARCH dynamics have been appropriately captured in the conditional variance-covariance equation, given by Equ. (4).

\footnotetext{
${ }^{10}$ We use the SIMPLEX free-derivative method, which is useful to improve the initial values, and then the BFGS standard algorithm to obtain the standard errors (see Engle and Kroner, 1995; Kearney and Patton, 2000; among others). This procedure was implemented in RATS 8.1 with a convergence criterion of 0.00001 .
} 


\section{Empirical results}

The objective of our analysis is to establish whether exchange rate uncertainty affects net equity and bond flows across borders, and also whether there is volatility transmission (hence information flows) between these flows and exchange rate changes and, if so, in what direction causality runs. ${ }^{11}$

The QML estimates of the bivariate VAR GARCH $(1,1)$-BEKK-in-mean parameters as well as the associated multivariate Q-statistics (Hosking, 1981) are displayed in Tables A1-A6 (see Appendix A) for Australia, Canada, the euro area, Japan, Sweden, and the UK, respectively. ${ }^{12}$ Panels A and B in each Table concern the bivariate regression of exchange rate changes against equity and bond flows respectively. The Hosking multivariate Q-statistics for (6) and (12) lag orders for the standardised residuals in the exchange rate changes-equity flows cases indicate no serial correlation at the $5 \%$ level, when the corresponding conditional mean equations are specified with $p=1$ for Japan, $p=2$ for Sweden and $p=3$ for the other countries (the insignificant parameters in the mean equations have been dropped ${ }^{13}$ ). With regard to the exchange rate changes-bond flows relationships, whilst no dynamic terms appear to be necessary for Sweden, setting $p=1$ for the UK, $p=2$ for the euro area, $p=3$ for Australia and Canada and $p=5$ for Japan is required to capture adequately the dynamic

\footnotetext{
${ }^{11}$ The impact of exchange rate uncertainty on aggregate flows is found for all countries to be rather similar to that on net equity and bond portfolio flows in terms of sign and statistical significance. However, knowledge about the specific linkages can be useful to regulatory authorities and policy-makers to target the appropriate market(s) to achieve economic and financial stability, as discussed earlier.

${ }^{12}$ We have also conducted the estimation using the diagonal BEKK model which restricts the spillover parameters $a_{12}, a_{21}, b_{12}$, and $b_{21}$ in Equ. (4) to zero. The results (available upon request) for the impact of exchange rate uncertainty on net flows are qualitatively similar.

${ }^{13}$ Parameters have been dropped from the models sequentially using the $10 \%$ level. Also, they were found to be jointly insignificant at the $10 \%$ level.
} 
structure in these cases. Also, the Hosking multivariate Q-statistics for (6) and (12) lag orders for the squared standardised residuals suggest that the multivariate GARCH $(1,1)$ structure is sufficient to capture the volatility in the series. Hence, the estimated models are shown to be well specified.

Table 3 reports a summary of the estimated results displayed in Tables A1-A6 (Appendix A). These suggest that there are limited dynamic linkages between the first moments compared to the second ones. The results in the conditional mean equations indicate the existence of bidirectional mean spillovers between exchange rate changes and net bond flows in Japan, as well as spillovers from net bond flows to exchange rate changes in Canada and the UK, and from net equity flows to exchange rate changes in the euro area.

\section{[Insert Table 3 about here]}

The results also suggest that exchange rate uncertainty affects net equity flows negatively in the euro area, Sweden, and the UK, and positively in Australia, and has no effect in Canada and Japan. Its impact on net bond flows, on the other hand, appears to be negative in all countries except Canada for which it is positive. In Fig. 1 we plot net equity and net bond flows, exchange rate changes, and the conditional variances of exchange rate changes for all countries over the sample period. It can be seen that the conditional variances of exchange rate changes, measured using the bivariate VAR GARCH-in-mean parameterisation, were high during the recent global financial crisis in most countries. ${ }^{14}$ The impact of the 1992 crisis is also apparent in the cases of the UK and the euro area. Interestingly, net inflows towards the US were low during the recent crisis period in most cases, and also during the 1992 crisis, especially for the UK. Overall, these plots support the econometric results implying that periods of high exchange rate uncertainty were associated

\footnotetext{
${ }^{14}$ See also Caporale et al. (2014) on the movements of the major currencies during the recent financial crisis.
} 
with declines in net flows. This holds in most cases, except Australia and Japan for net equity flows and Canada for both net equity and net bond flows.

The estimated negative impact of exchange rate uncertainty on net equity as well as net bond flows has important implications. First, it indicates that risk-averse market participants, especially those of the counterparties to the US, respond to exchange rate uncertainty by reducing their financial activities, and favouring domestic rather than foreign securities in their portfolios to minimise their exposure to uncertainty. This finding is broadly consistent with the evidence in Bayoumi (1990), Iwamoto and van Wincoop (2000), and Bacchetta and van Wincoop (1998, 2000). While Bayoumi (1990) showed that net capital flows as a share of GDP are lower during the floating exchange rate period (1965-1986) than during the gold standard (1880-1913), Iwamoto and van Wincoop (2000) reported that net capital flows as a fraction of GDP are much larger across regions of a country, which use the same currency, than across countries. Bacchetta and van Wincoop (1998, 2000), on the other hand, showed that exchange rate uncertainty should dampen net international capital flows in the context of a two-period general equilibrium model.

Second, in contrast to Hau and Rey (2006), who assumed that bonds are hedged instruments not affected by exchange rate uncertainty, it appears that uncertainty in fact affects bond as well as equity flows, and the former more widely, since a negative impact is found in five of the six countries examined (see also Fig. 1). This is consistent with the results of Fidora et al. (2007), who found that exchange rate volatility is an important factor for bilateral portfolio home bias, this being higher for bonds than for equities. This finding has recently been confirmed by Bekaert and Wang (2009) and Borensztein and Loungani (2011), although in the former study it is not found to be economically significant. The rationalisation of Fidora et al. (2007) of the higher home bias for bonds compared to equities is that it is consistent with Markowitz-type international CAPM specifications in which less volatile financial assets should be characterised by a larger home bias. 
However, the results indicate that exchange rate uncertainty does not induce home bias in Australia and Japan for equity flows and in Canada for both equity and bond flows (see also Fig. 1). The finding that exchange rate uncertainty has a positive effect on net equity flows in Australia is consistent with the evidence in Batten and Vo (2010) and Daly and Vo (2013), whilst Mishra (2011) found a negative effect. A possible explanation for the findings of Australia and Canada may be that they are commodity-exporting countries and developments in their financial markets are driven by terms-of-trade shocks. Chaban (2009) and Ferreira Filipe (2012) indeed found that the portfolio-rebalancing motive of Hau and Rey (2006) in these countries is weak. Chaban (2009) argued that commodity prices play a significant role in the transmission of shocks in these countries, and Ferreira Filipe (2012) found that differences in the volatility of country-specific shocks also do so. Japan is a special case: as highlighted by Hau and Rey (2006), bond flows represent most of the international portfolio flows for this country, even though a high percentage of Japanese debt is financed internally.

The estimates of the conditional variance equations indicate that the conditional variances exhibit persistence in all cases except for net equity flows in Canada (see Tables A1-A6 in Appendix A). While the persistence of the conditional variance of exchange rate changes ranges from 0.54 (Japan) to 0.98 (euro area), that of the corresponding flows ranges from 0.38 (Sweden) to 0.91 (euro area) for net equity flows and from 0.43 (Japan) to 0.98 (Canada) for net bond flows. The ARCH, $a_{11}$, and GARCH, $b_{11}$, parameter estimates for exchange rate changes in the bivariate GARCH-BEKK models are rather similar, regardless of whether the relationship with net bond or equity flows is considered (see Panels A and B respectively in all Tables). More specifically, $a_{11}$ changes by a magnitude of less than 0.10 and this also applies to $b_{11}$, except for Japan where it is around 0.26 . 
Furthermore, the off-diagonal elements of the ARCH and GARCH matrices suggest the following: statistically significant volatility spillovers running from net equity flows to exchange rate changes (measured by $b_{21}$ ) in the cases of Canada and the UK; both shock (measured by $a_{21}$ ) and volatility (measured by $b_{21}$ ) spillovers from net equity flows to exchange rate changes in the case of Sweden, and bidirectional volatility spillovers (measured by $b_{21}$ and $b_{12}$ ) for Japan. The results also show that net bond flows' shocks affect the volatility of exchange rate changes $\left(a_{21}\right)$ in the case of Australia; shock and volatility spillovers running from exchange rate changes to net bond flows are present for Canada, whereas for Sweden they run in the opposite direction; in the case of Japan there are volatility spillovers from exchange rate changes to net bond flows. In the euro area and the UK the volatility spillovers between net bond flows and exchange rate changes are bidirectional. Finally, exchange rates’ shocks are found to affect the volatility of net bond flows in the UK, whereas in the euro area shock spillovers run in the opposite direction.

Broadly speaking, these findings are consistent with those of the causality-in-variance (i.e., the information flow) test results (Table 3). More specifically, the Wald test statistics (see Tables A1-A6) provide evidence of strong causality-in-variance from net equity flows to exchange rate changes in the case of the UK and Sweden, and bidirectional causality-invariance in the case of Japan. There is also causality-in-variance from net bond flows to exchange rate changes in Australia and Sweden, and causality in the reverse direction in Canada, as well as bidirectional causality in the rest of the countries. A possible explanation for the existence of stronger dynamic linkages between exchange rate changes and bond flows instead of equity flows is that foreign exchange dealers usually follow bond yields in their trading behaviour; these yields, in turn, drive cross-border bond acquisitions, which results in volatile exchange rates. Spillovers from the exchange rates may be due to the fact that investors adjust their portfolios on the basis of their volatility. 
Finally, Fig. 2 displays the evolution of the dynamic conditional correlation between exchange rate changes and net flows to provide further insights into the dependence between these variables. The graphical analysis indicates that these correlations are time-varying in most cases. Furthermore, there are clear shifts during turbulent periods such as the 1992 crisis in the case of the UK, and the recent global financial crisis of 2007-2009 in most cases. These plots confirm the existence of strong linkages between exchange rate changes and net flows during such periods, as found before.

\section{Conclusions}

In this paper, we have analysed the impact of exchange rate uncertainty on net bond and net equity flows, as well as the dynamic linkages between exchange rate volatility and the variability of these flows, using monthly data for the US vis-à-vis six advanced economies, namely Australia, Canada, the euro area, Japan, Sweden, and the UK over the period 1988:012011:12. By estimating bivariate VAR GARCH-BEKK-in-mean models, we find evidence that exchange rate uncertainty impacts on net equity flows negatively in the euro area, Sweden, and the UK and positively in Australia. Furthermore, in contrast to the assumption of Hau and Rey (2006), it also affects net bond flows negatively in all countries except Canada, where the effect is positive. The general conclusion that can be drawn from these results is that exchange rate uncertainty induces risk-averse investors, especially those of the counterparties to the US, to reduce their financial activities and to favour domestic rather than foreign assets in their portfolios in order to minimise their exposure to uncertainty. This evidence is stronger in the case of the UK, the euro area and Sweden compared to Canada, Australia and Japan. The results for Australia, Canada and Japan may be due to the specific characteristics of these economies, as documented in other studies (e.g., Hau and Rey, 2006; Chaban, 2009; and Ferreira Filipe, 2012). 
The causality-in-variance analysis suggests the existence of strong spillovers from net equity flows to exchange rate changes in the UK and Sweden, and bidirectional causality-invariance in Japan. Causality-in-variance is also found to run from net bond flows to exchange rate changes in Australia and Sweden, in the opposite direction in Canada, and in both directions in the other countries.

Overall, our findings have important policy implications that are country-specific. In particular, they suggest that policy-makers and economic and financial regulators in countries with strong uncertainty effects can use exchange rate or credit controls on equity as well as bond flows as instruments to achieve economic and financial stability. 


\section{Appendix A}

[Insert Tables A1-A6 about here]

\section{References}

Bacchetta, P., van Wincoop, E., 1998. Does exchange rate stability increase trade and capital flows? NBER Working Paper 6704.

Bacchetta, P., van Wincoop, E., 2000. Trade in nominal assets and net international capital flows. Journal of International Money and Finance 19, 55-72.

Batten, J.A., Vo, X.V., 2010. The determinants of equity portfolio holdings. Applied Financial Economics 20 (14), 1125-1132.

Bauwens, L., Laurent, S., Rombouts, J.V.K., 2006. Multivariate GARCH models: a survey. Journal of Applied Econometrics 21, 79-109.

Bayoumi, T.A., 1990. Saving-investment correlations: immobile capital, government policy or endogenous behaviour? IMF Staff Papers 37, 360-387.

Bekaert, G., Harvey, C.R., Lumsdaine, R.L., 2002. The dynamics of emerging market equity flows. Journal of International Money and Finance 21 (3), 295-350.

Bekaert, G., Wang, X., 2009. Home bias revisited. Available at SSRN: http://ssrn.com/abstract=1344880.

Bohn, H., Tesar, L.L., 1996. U.S. equity investment in foreign markets: portfolio rebalancing or return chasing?, American Economic Review 86 (2), 77-81.

Bollerslev, T.P, Engle, R.F., Wooldridge, J.M., 1988. A capital asset pricing model with time varying covariances. Journal of Political Economy 96, 116-131.

Bollerslev, T.P., Wooldridge, J.M., 1992. Quasi-maximum likelihood estimation and inference in dynamic models with time-varying covariances. Econometric Reviews 11, 143-72. 
Borensztein, E., Loungani, P., 2011. Asian financial integration: trends and interruptions. International Monetary Fund Working Paper, WP/11/14 (Washington, DC: International Monetary Fund).

Brennan, M.J., Cao, H.H., 1997. International portfolio investment flows. The Journal of Finance 52, 1851-1880.

Brooks, R., Edison, H., Kumar, M.S., Sløk, T., 2004. Exchange rates and capital flows. European Financial Management 10, 511-533.

Caporale, G.M., Hunter, J., Menla Ali, F., 2014. On the linkages between stock prices and exchange rates: evidence from the banking crisis of 2007-2010. International Review of Financial Analysis 33, 87-103.

Caporin, M., McAleer, M., 2012. Do we really need both BEKK and DCC? A tale of two multivariate GARCH models. Journal of Economic Surveys 26, 736-751.

Chaban, M., 2009. Commodity currencies and equity flows. Journal of International Money and Finance 28, 836-852.

Cheung,Y.W., Ng, L.K., 1996. A causality in variance test and its application to financial market prices. Journal of Econometrics 72, 33-48.

Chinn, M.D., Moore, M., 2011. Order flow and the monetary model of exchange rates: evidence from a novel data set. Journal of Money, Credit and Banking 43, 1599-1624.

Choi, J.J., Rajan, M., 1997. A joint test of market segmentation and exchange risk factor in international capital markets. Journal of International Business Studies, 28 (1), 29-49.

Daly, K., Vo, X.V., 2013. The determinants of home bias puzzle in equity portfolio investment in Australia. International Review of Financial Analysis 27, 34-42.

Duffuor, K., Marsh, I.W., Phylaktis, K., 2012. Order flow and exchange rate dynamics: an application to emerging markets. International Journal of Finance and Economics 17, 290-304. 
Edison, H.J., Warnock, F.E., 2008. Cross-border listings, capital controls, and equity flows to emerging markets. Journal of International Money and Finance 27, 1013-1027.

Elder, J., Serletis, A., 2010., Oil price uncertainty. Journal of Money, Credit and Banking 42(6), 1137-1159.

Engle, R.F., 1982. Autoregressive conditional heteroskedasticity with estimates of the variance of U.K. inflation. Econometrica 50, 987-1008.

Engle, R.F., 2002. Dynamic conditional correlation- a simple class of multivariate GARCH models. Journal of Business \& Economic Statistics 20, 339-350

Engle, R.F., Kroner, K.F., 1995. Multivariate simultaneous generalized ARCH. Econometric Theory 11, 122-150.

Eun, C.S., Resnick, B.G., 1988. Exchange rate uncertainty, forward contracts, and international portfolio selection. The Journal of Finance 43, 197-215.

Eun, C.S., Resnick, B.G., 1994. International diversification of portfolio investment: U.S. and Japanese perspectives. Management Science 40, 140-161.

Evans, M., Lyons, R.K., 2002. Order flow and exchange rate dynamics. Journal of Political Economy 110, 170-180.

Evans, M., Lyons, R.K., 2005. Meese-Rogoff redux: micro-based exchange rate forecasting. American Economic Review 95 (2), 405-414.

Evans, M., Lyons, R.K., 2008. How is macro news transmitted to exchange rates? Journal of Financial Economics 88, 26-50.

Ferreira Filipe, S.F., 2012. Equity order flow and exchange rate dynamics. Journal of Empirical Finance 19, 359-381.

Fidora, M., Fratzscher, M., Thimann, C., 2007. Home bias in global bond and equity markets: the role of real exchange rate volatility. Journal of International Money and Finance 26, 631-655. 
Fratzscher, M., 2012. Capital flows, push versus pull factors and the global financial crisis. Journal of International Economics 88, 341-356.

Grier, K.B., Henry, O.T., Olekalns, N., Shields, K., 2004. The asymmetric effects of uncertainty on inflation and output growth. Journal of Applied Econometrics 5, 551-565.

Grier, K.B., Smallwood, A.D., 2013. Exchange rate shocks and trade: a multivariate GARCHM approach. Journal of International Money and Finance 37, 282-305.

Gehrig, T., 1993. An information based explanation of the domestic bias in international equity investment. The Scandinavian Journal of Economics 95(1), 97-109.

Glen, J., Jorion, P., 1993. Currency hedging for international portfolios. The Journal of Finance 48, 1865-1886.

Hafner, C.M., Herwartz, H., 2008. Testing for causality in variance using multivariate GARCH models. Annals of Economics and Statistics 89, 215-241.

Hau, H., Rey, H., 2006. Exchange rates, equity prices, and capital flows. The Review of Financial Studies 19, 273-317.

Hosking, J.R.M., 1981. Equivalent forms of the multivariate portmanteau statistic. Journal of the Royal Statistical Society 43, 261-262.

Iwamoto, Y., van Wincoop, E., 2000. Do borders matter? evidence from Japanese regional net capital flows. International Economic Review 41(1), 241-269.

Jorion, P., 1991. The pricing of exchange rate risk in the stock market. The Journal of Financial and Quantitative Analysis 26 (3), 363-376.

Kearney, C., Patton, A.J., 2000. Multivariate GARCH modeling of exchange rate volatility transmission in the European Monetary System. The Financial Review 35, 29-48.

Kodongo, O., Ojah, K., 2012. The dynamic relation between foreign exchange rates and international portfolio flows: evidence from Africa’s capital markets. International Review of Economics and Finance 24, 71-87. 
Kroner, K.F., Lastrapes, W.D., 1993. The impact of exchange rate volatility on international trade: reduced form estimates using the GARCH-in-mean model. Journal of International Money and Finance 12, 298-318.

Levich, R.M., Hayt, G.S., Ripston, B.A., 1999. 1998 survey of derivative and risk management practices by U.S. institutional investors, Survey conducted by the NYU Salomon Center, CIBC World Markets, and KPMG, available at http://papers.ssrn.com/sol3/papers.cfm?abstract_id=204388.

McKenzie, M.D., 1999. The impact of exchange rate volatility on international trade flows. Journal of Economic Surveys 13, 71-106.

Mercado, R., 2013. Emerging Asia equity home bias and financial integration. International Economic Journal 27 (4), 497-524.

Mishra, A.V. 2011. Australia’s equity home bias and real exchange rate volatility. Review of Quantitative Finance and Accounting 37 (2), 223-244.

Payne, R., 2003. Informed trade in spot foreign exchange markets: an empirical investigation. Journal of International Economics 61, 307-329.

Portes, R., Rey, H., Oh, Y., 2001. Information and capital flows: the determinants of transactions in financial assets. European Economic Review 45, 783-796.

Portes, R., Rey, H., 2005. The determinants of cross-border equity flows. Journal of International Economics 65, 269-296.

Rahman, S., Serletis, A., 2012. Oil price uncertainty and the Canadian economy: evidence from a VARMA, GARCH-in-Mean, asymmetric BEKK model. Energy Economics 34, 603-610.

Rime, D., Sarno, L., Sojli, E., 2010. Exchange rate forecasting, order flow and macroeconomic information. Journal of International Economics 80, 72-88.

Ross, S.A., 1989. Information and volatility: the no-arbitrage martingale approach to timing and resolution irrelevancy. The Journal of Finance 44, 1-17. 
Siourounis, G., 2004. Capital flows and exchange rates: an empirical analysis. Available at: http://papers.ssrn.com/sol3/papers.cfm?abstract_id=572025. 
Table 1

Summary of descriptive statistics for the scaled (or adjusted) net portfolio flows and exchange rate changes.

\begin{tabular}{llllllll}
\hline Statistics & Variable & Australia & Canada & Euro area & Japan & Sweden & UK \\
\hline Mean & $E_{t}$ & -0.122 & 0.083 & -0.002 & 0.160 & -0.047 & -0.066 \\
& $E F_{t}$ & -0.200 & 0.068 & -0.051 & -0.432 & 0.020 & -0.017 \\
& $B F_{t}$ & -0.106 & 0.191 & 0.222 & 0.718 & 0.260 & 0.848 \\
St. Dev & $E_{t}$ & 3.270 & 2.148 & 3.080 & 3.088 & 3.439 & 2.855 \\
& $E F_{t}$ & 1.599 & 1.443 & 1.487 & 1.552 & 1.729 & 1.414 \\
& $B F_{t}$ & 1.467 & 1.394 & 1.358 & 1.251 & 1.638 & 1.136 \\
Skewness & $E_{t}$ & 0.790 & -0.692 & -0.375 & 0.221 & -0.554 & -0.738 \\
& $E F_{t}$ & -1.129 & 0.144 & 0.028 & -0.631 & -1.333 & -0.342 \\
\multirow{3}{*}{ Ex. kurtosis } & $B F_{t}$ & -0.446 & -0.202 & -0.365 & 0.634 & 0.379 & -0.385 \\
& $E_{t}$ & 6.226 & 9.417 & 4.119 & 4.958 & 5.410 & 5.634 \\
& $E F_{t}$ & 10.619 & 4.301 & 4.157 & 6.103 & 8.363 & 3.607 \\
JB & $B F_{t}$ & 4.988 & 3.830 & 3.665 & 7.905 & 7.914 & 9.786 \\
& $E_{t}$ & $154.31^{* * *}$ & $515.38^{* * *}$ & $21.713^{* * *}$ & $48.195^{* * *}$ & $84.171^{* * *}$ & $109.07^{* * *}$ \\
& $E F_{t}$ & $755.30^{* * *}$ & $21.262^{* * *}$ & $16.065^{* * *}$ & $134.21^{* * *}$ & $429.01^{* * *}$ & $10.021^{* * *}$ \\
& $B F_{t}$ & $56.834^{* * *}$ & $10.207^{* * *}$ & $11.691^{* * *}$ & $306.95^{* * *}$ & $295.67^{* * *}$ & $557.86^{* * *}$ \\
\hline
\end{tabular}

Notes: $E_{t}, E F_{t}$, and $B F_{t}$ indicate exchange rate changes, net equity flows, and net bond flows, respectively; JB is the Jarque-Bera test for normality.

${ }^{* * *}$ indicates significance at the $1 \%$ level.

Table 2

LM ARCH test statistics for the residuals of the bivariate VAR model of exchange rate changes and net flows.

\begin{tabular}{llllllll}
\hline & & Australia & Canada & Euro area & Japan & Sweden & UK \\
\hline Panel A & $\varepsilon_{1, t}$ & $3.135[0.000]$ & $1.857[0.088]$ & $1.904[0.080]$ & $1.952[0.072]$ & $3.290[0.003]$ & $2.767[0.012]$ \\
& $\varepsilon_{2, t}$ & $1.588[0.150]$ & $4.934[0.000]$ & $1.868[0.086]$ & $1.951[0.072]$ & $2.421[0.026]$ & $4.229[0.000]$ \\
Panel B & & & & & & & \\
& $\varepsilon_{1, t}$ & $3.342[0.003]$ & $1.990[0.067]$ & $2.444[0.025]$ & $1.971[0.069]$ & $2.545[0.020]$ & $2.887[0.009]$ \\
& $\varepsilon_{2, t}$ & $2.374[0.029]$ & $4.218[0.000]$ & $0.592[0.736]$ & $2.153[0.047]$ & $3.022[0.007]$ & $8.266[0.000]$ \\
\hline
\end{tabular}

Notes: Panel A (B) indicates the bivariate VAR model for exchange rate changes and net equity (bond) flows. The bivariate VAR model is modelled as

$$
y_{t}=\mu+\sum_{i=1}^{p} \Psi_{i} y_{t-i}+\varepsilon_{t} \text {, where } \mu=\left[\begin{array}{l}
\mu_{1} \\
\mu_{2}
\end{array}\right] ; \Psi_{i}=\left[\begin{array}{cc}
\psi_{11}^{(i)} & \psi_{12}^{(i)} \\
\psi_{21}^{(i)} & \psi_{22}^{(i)}
\end{array}\right] ; \varepsilon_{t}=\left[\begin{array}{c}
\varepsilon_{1, t} \\
\varepsilon_{2, t}
\end{array}\right] \text {. }
$$

Lags of the model are added sequentially until serial correlation is removed by employing the Hosking (1981) multivariate Q statistics on the residuals. ARCH tests are conducted on the residuals $\varepsilon_{s, t}$, where $s=1$ (for exchange rate changes $\left(E_{t}\right)$ ), 2 (for net equity flows $\left(E F_{t}\right)$ and net bond flows $\left(B F_{t}\right)$ ), using a lag order of (6). $P$-values are represented in square brackets [.]. 


\section{Table 3}

Summary of estimated results for the conditional mean and conditional variance equations.

\begin{tabular}{|c|c|c|c|c|}
\hline Australia & Canada & Euro area & Japan & Sweden \\
\hline
\end{tabular}

Panel A. Mean spillovers between exchange rates and net flows
$E_{t}$ and $E F_{t}$ case
$E F_{t} \rightarrow E_{t}$
$E_{t}$ and $B F_{t}$ case
$B F_{t} \rightarrow E_{t}$
$B F_{t} \leftrightarrow E_{t}$
$B F_{t} \rightarrow E_{t}$

Panel B. Exchange rate uncertainty effects on net flows
Net equity flows
$(+)$
$(-)$
$(-)$
$(-)$
Net bond flows
$(-)$
$(+)$
$(-)$
$(-)$
$(-)$
$(-)$

Panel C. Causality-in-variance tests between exchange rate changes and net flows
$E_{t}$ and $E F_{t}$ case
$E F_{t} \leftrightarrow E_{t} \quad E F_{t} \rightarrow E_{t} \quad E F_{t} \rightarrow E_{t}$
$E_{t}$ and $B F_{t}$ case
$B F_{t} \rightarrow E_{t} \quad E_{t} \rightarrow B F_{t}$
$B F_{t} \leftrightarrow E_{t}$
$B F_{t} \leftrightarrow E_{t} \quad B F_{t} \rightarrow E_{t}$
$B F_{t} \leftrightarrow E_{t}$

Notes: $E_{t}, E F_{t}$, and $B F_{t}$ indicate exchange rate changes, net equity flows, and net bond flows, respectively. $\rightarrow$ indicates the direction of causality or spillovers, while $\leftrightarrow$ indicates that the causality or spillovers are bidirectional. $(-)$ and $(+)$ denote the corresponding sign of the impact of exchange rate uncertainty on net flows. Only significant results in the conditional mean equations from Tables A1-A6 (see Appendix A) are reported in Panels A and B, while results of the causality-in-variance tests reported in Panel C are those confirming the existence of spillovers based on the Wald tests reported in the corresponding Tables. 


\section{Australia}

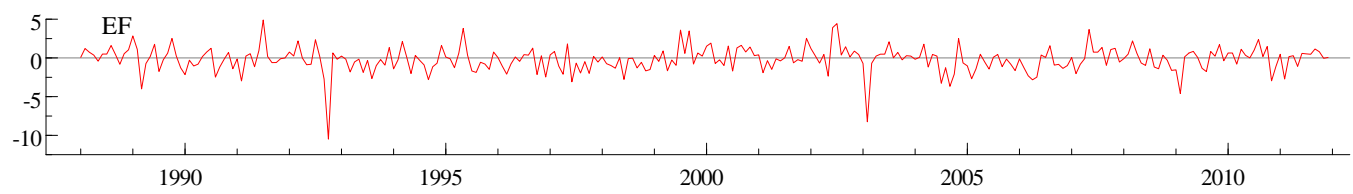

$\underbrace{25 F}_{1990}$
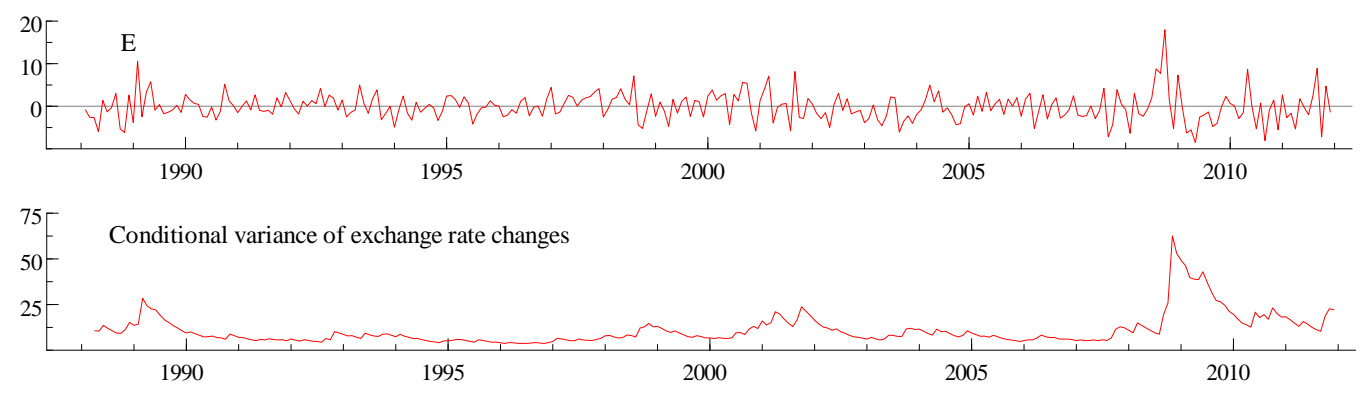

\section{Canada}
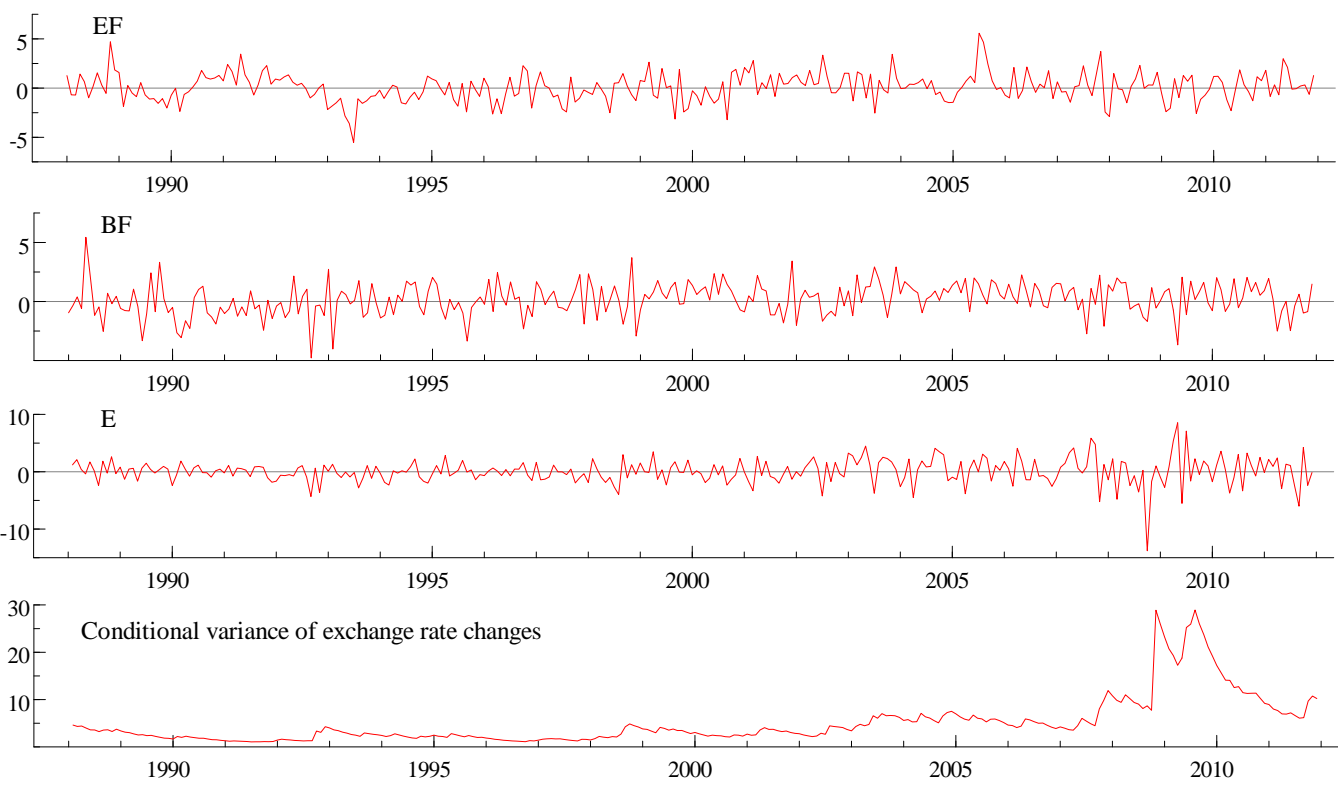

Fig. 1. Net equity flows $\left(E F_{t}\right)$, net bond flows $\left(B F_{t}\right)$, exchange rate changes $\left(E_{t}\right)$, and the conditional variance of exchange rate changes. 


\section{Euro area}
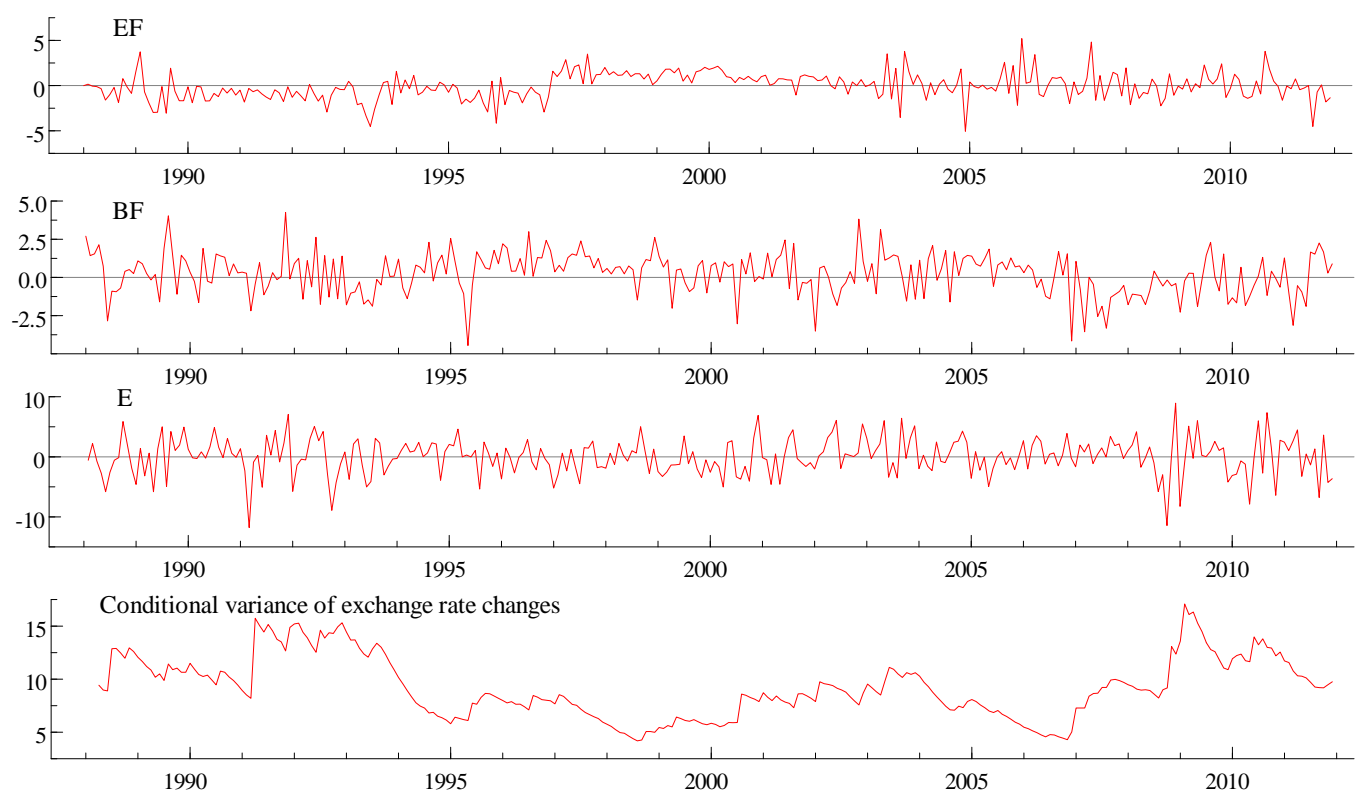

Japan
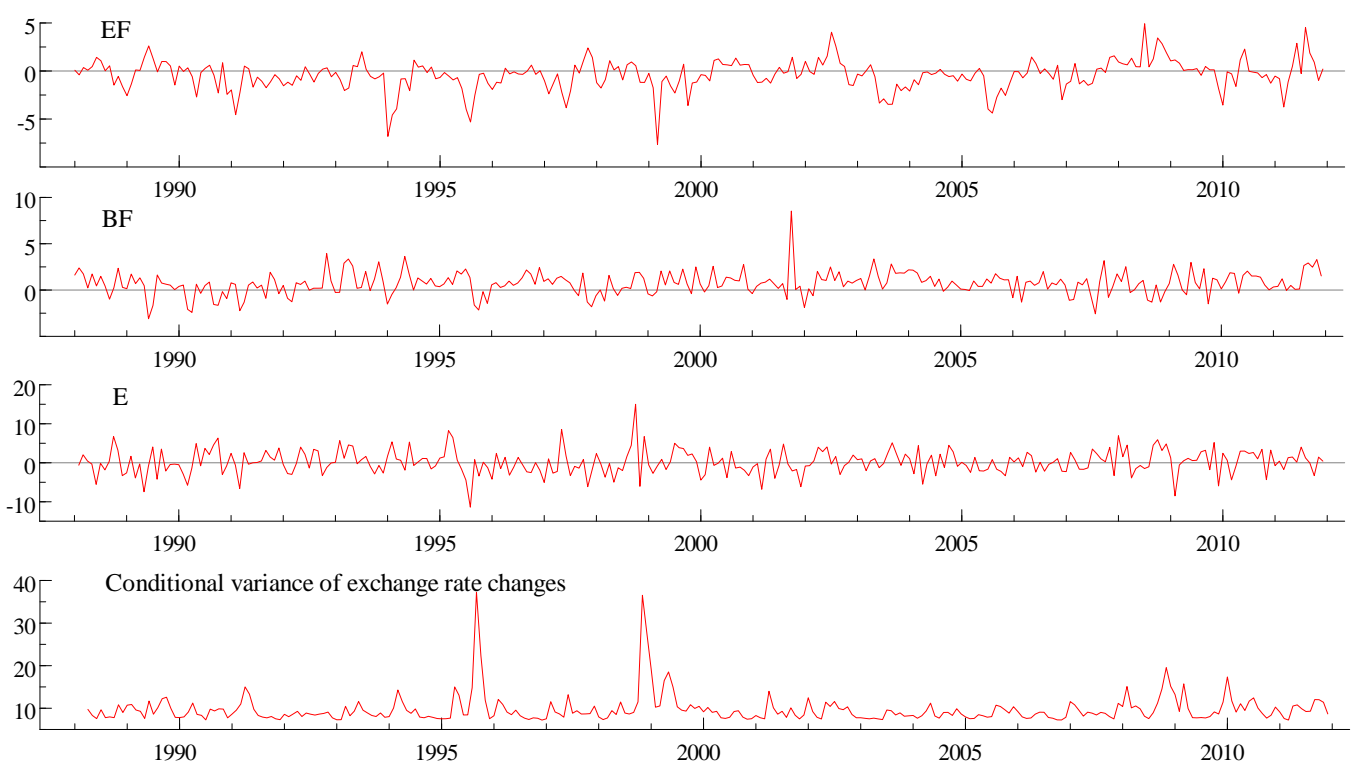

Fig. 1 (continued). Net equity flows $\left(E F_{t}\right)$, net bond flows $\left(B F_{t}\right)$, exchange rate changes $\left(E_{t}\right)$, and the conditional variance of exchange rate changes. 


\section{Sweden}
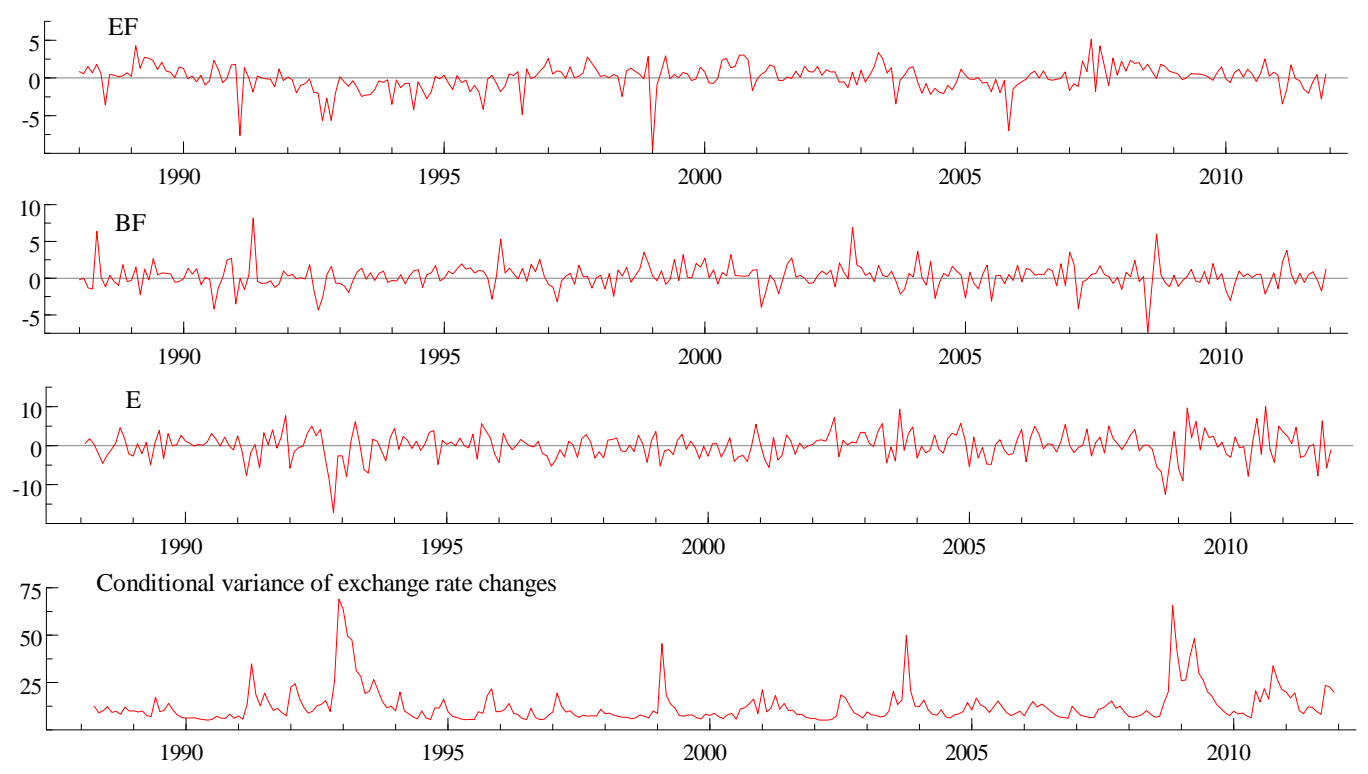

\section{UK}
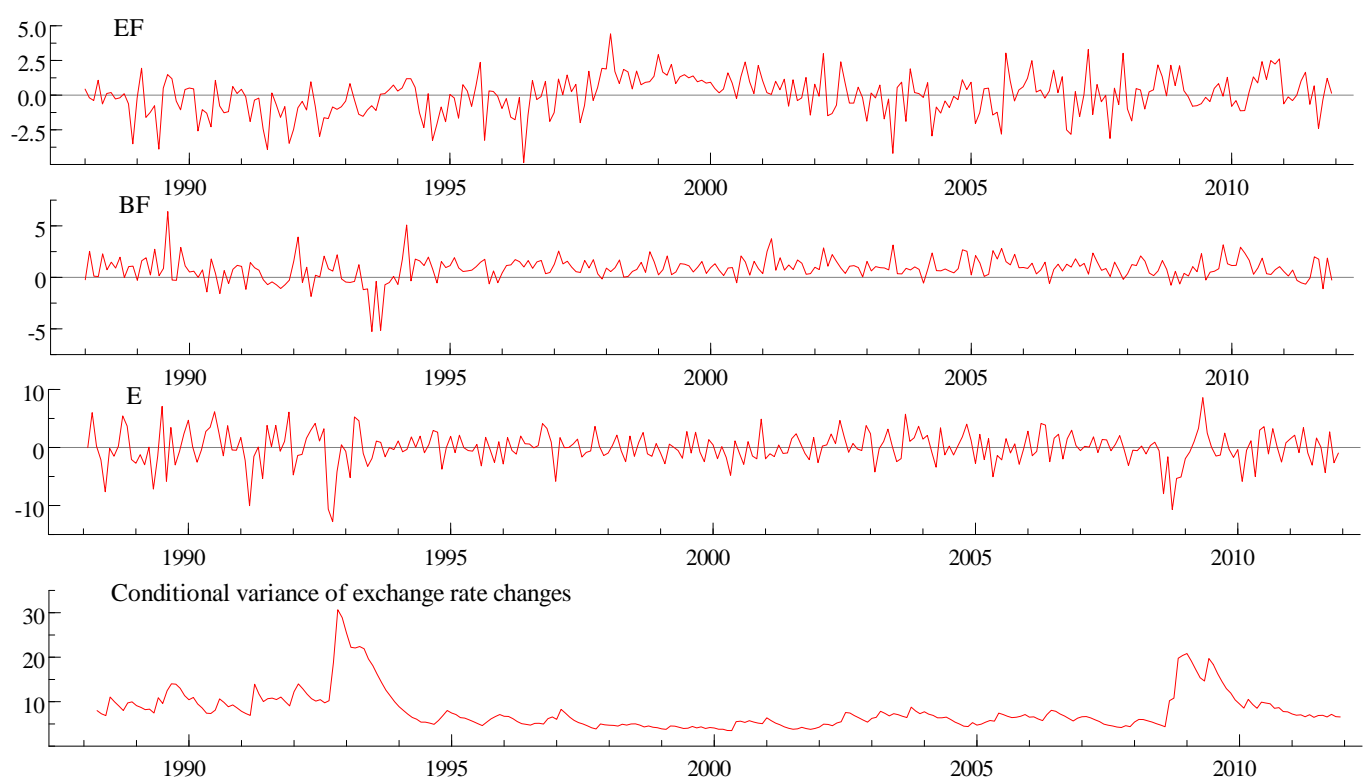

Fig. 1 (continued). Net equity flows $\left(E F_{t}\right)$, net bond flows $\left(B F_{t}\right)$, exchange rate changes $\left(E_{t}\right)$, and the conditional variance of exchange rate changes. 
Australia
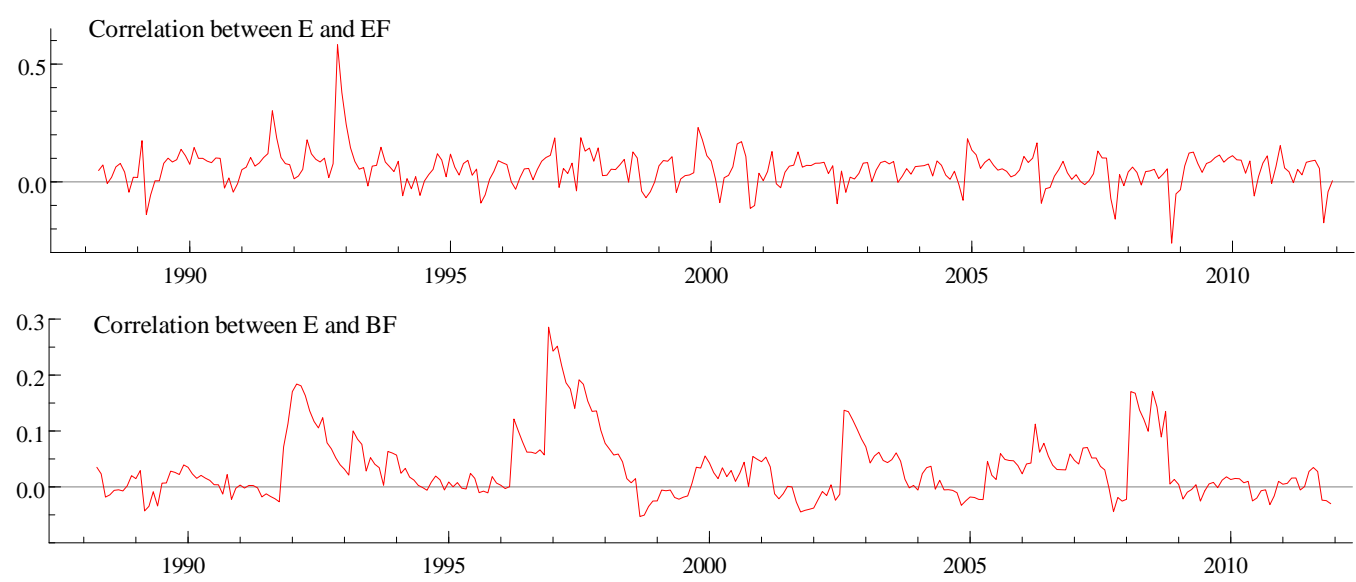

Canada
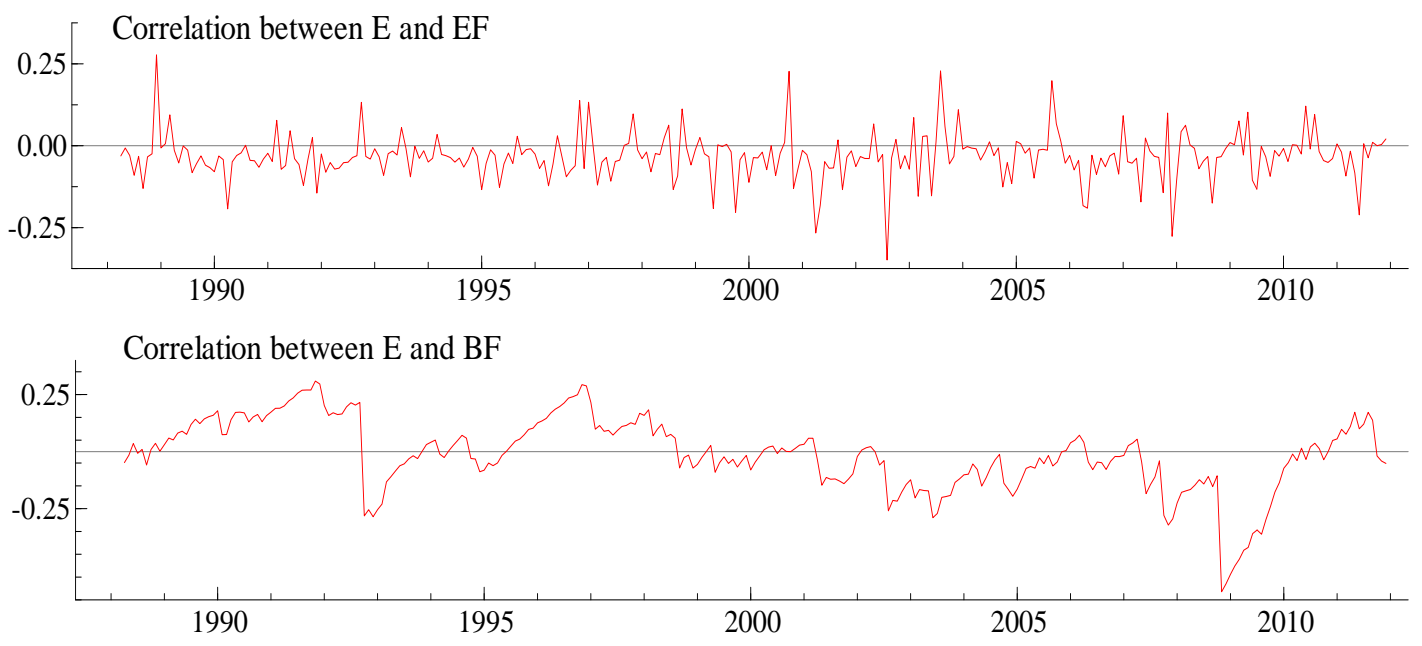

Euro area
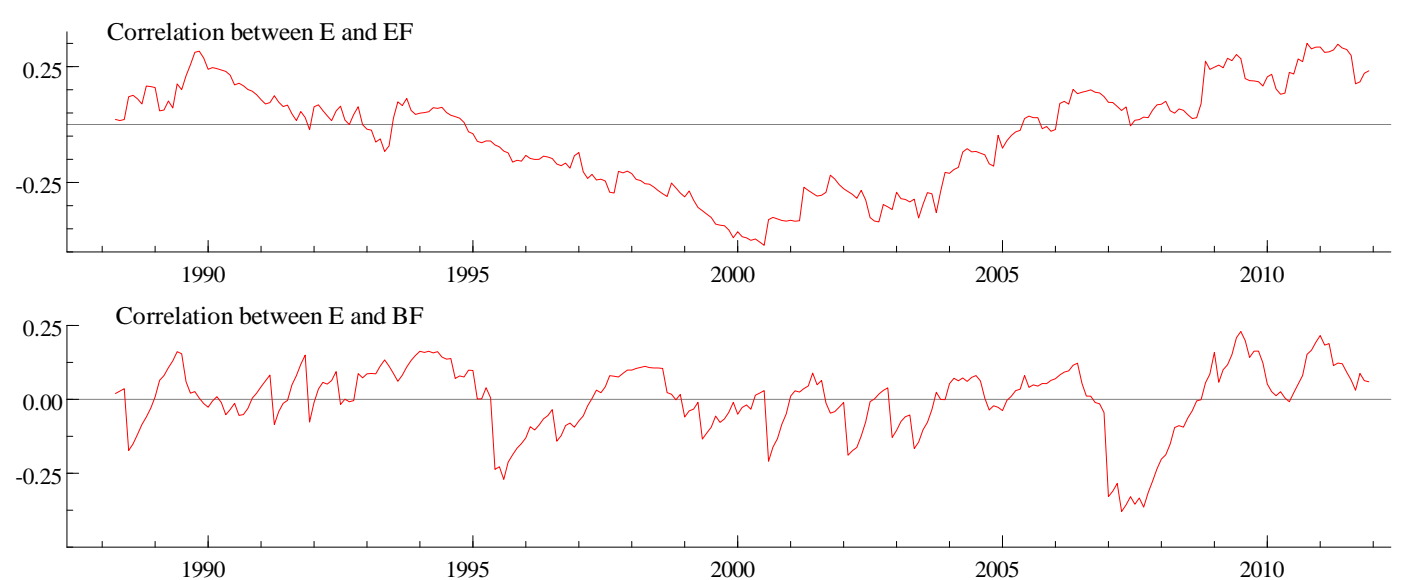

Fig. 2. The evolution of the dynamic conditional correlations between exchange rate changes $\left(E_{t}\right)$ and net equity $\left(E F_{t}\right)$ and net bond flows $\left(B F_{t}\right)$ (calculated as $\left.h_{12} / \sqrt{h_{11, t}} \sqrt{h_{22, t}}\right)$. 
Japan
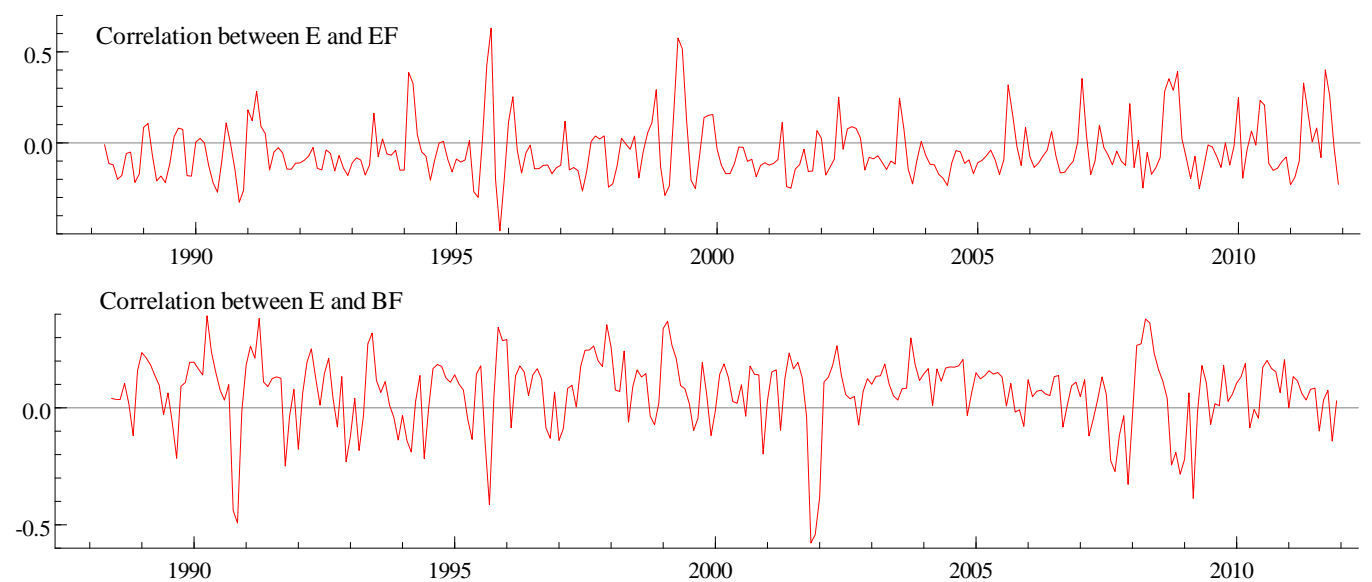

Sweden
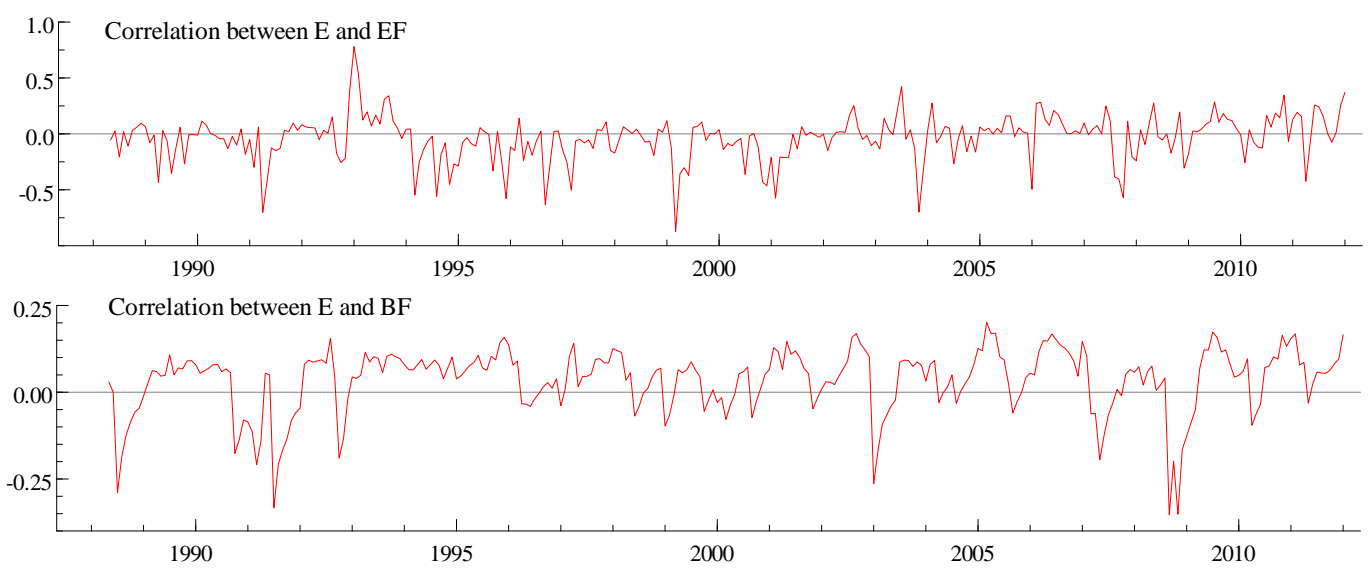

UK
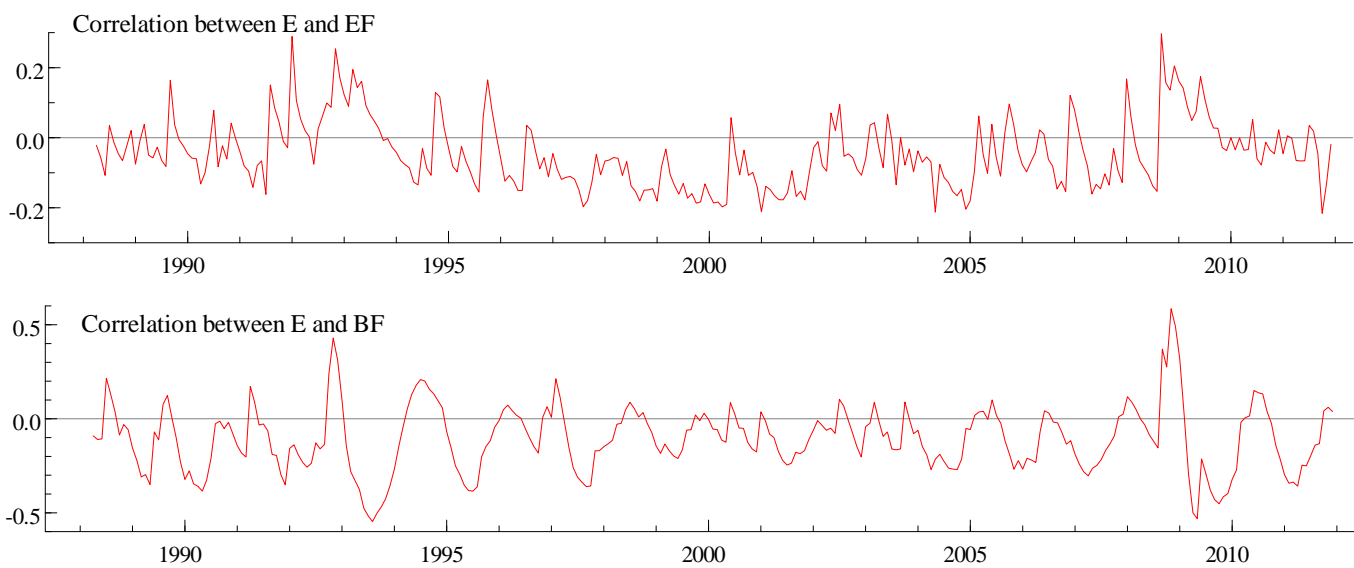

Fig. 2 (continued). The evolution of the dynamic conditional correlations between exchange rate changes $\left(E_{t}\right)$ and net equity $\left(E F_{t}\right)$ and net bond flows $\left(B F_{t}\right)$ (calculated as $h_{12} / \sqrt{h_{11, t}} \sqrt{h_{22, t}}$ ). 


\section{Table A1}

The estimated bivariate VAR GARCH-BEKK-in-mean model for Australia.

\begin{tabular}{|c|c|c|c|c|c|}
\hline \multicolumn{3}{|c|}{ Panel A. Exchange rates $\left(E_{t}\right)$ and equity flows $\left(E F_{t}\right)$} & \multicolumn{3}{|c|}{ Panel B. Exchange rates $\left(E_{t}\right)$ and bond flows $\left(B F_{t}\right)$} \\
\hline & $E_{t}(s=1)$ & $E F_{t}(s=2)$ & & $E_{t}(s=1)$ & $B F_{t}(s=2)$ \\
\hline \multicolumn{6}{|c|}{ Conditional Mean Equation } \\
\hline$\mu_{\mathrm{s}}$ & $-\underset{(0.159)}{0.015}$ & $-{ }_{(0.120)}^{0.348^{* * *}}$ & $\mu_{s}$ & $-\underset{(0.157)}{0.128}$ & $\underset{(0.129)}{0.158}$ \\
\hline$\psi_{2 s}^{(1)}$ & & $\begin{array}{l}0.157^{* * *} \\
(0.079)\end{array}$ & $\psi_{2 s}^{(3)}$ & & $\begin{array}{l}0.129^{* * *} \\
(0.049)\end{array}$ \\
\hline$\psi_{1 s}^{(3)}$ & $\underbrace{0.110^{*}}_{(0.062)}$ & & $\phi_{2 s}^{(0)}$ & $-\underbrace{0.026^{* *}}_{(0.010)}$ & \\
\hline$\phi_{2 s}^{(5)}$ & ${ }_{(0.007)}^{0.014^{*}}$ & & & & \\
\hline
\end{tabular}

Conditional Variance Equation

\begin{tabular}{|c|c|c|c|c|c|c|}
\hline$C_{1 s}$ & $0_{(0.496)}^{0.496^{* * *}}$ & & $C_{1 s}$ & $-\underset{(0.281)}{0.103}$ & & \\
\hline$c_{2 s}$ & $-\underset{(1.760)}{0.042}$ & $\underbrace{1.352^{* *}}_{(0.545)}$ & $c_{2 s}$ & $\underbrace{0.753^{* * *}}_{(0.129)}$ & & $-\underset{(1.148)}{0.001}$ \\
\hline$a_{1 s}$ & ${ }_{(0.087)}^{0.363^{* * *}}$ & $\begin{array}{c}0.027 \\
(0.058)\end{array}$ & $a_{1 s}$ & $\begin{array}{l}0.254^{* * *} \\
(0.046)\end{array}$ & & $-\underset{(0.030)}{0.011}$ \\
\hline$a_{2 s}$ & $-\underset{(0.241)}{0.133}$ & $-\underset{(0.311)}{0.205}$ & $a_{2 s}$ & $\underbrace{0.380^{* * *}}_{(0.076)}$ & & $\underset{(0.152)}{0.076}$ \\
\hline$b_{1 s}$ & ${ }_{(0.037)}^{0.920^{* * *}}$ & $\underset{(0.039)}{0.014}$ & $b_{1 s}$ & ${ }_{(0.010)}^{0.949^{* * *}}$ & & $\underset{(0.004)}{0.001}$ \\
\hline$b_{2 s}$ & $\underset{(0.785)}{0.062}$ & $\underbrace{0.472^{*}}_{(0.256)}$ & $b_{2 s}$ & $\begin{array}{c}0.033 \\
(0.071) \\
\end{array}$ & & $\begin{array}{l}0.849^{* * *} \\
(0.065)\end{array}$ \\
\hline$\overline{\text { Loglik }}$ & -1254.543 & & Loglik & -1225.385 & & \\
\hline$Q(6)$ & $27.654[0.274]$ & $Q^{2}(6) \quad 9.823[0.981]$ & $Q(6)$ & 12.073 [0.979] & $Q^{2}(6)$ & $26.041[0.204]$ \\
\hline$Q(12)$ & $49.470[0.414]$ & $Q^{2}(12) 30.46[0.952]$ & $Q(12)$ & 31.67 [0.966] & $Q^{2}(12)$ & ) 48.899 [0.319] \\
\hline
\end{tabular}

\section{Hypotheses testing}

(i) No causality-in-variance from $E_{t}$ to $E F_{t}$

$H_{0}: a_{12}=b_{12}=0 \quad W=0.199$ [0.904]

(ii) No causality-in-variance from $E F_{t}$ to $E_{t}$

$H_{0}: a_{21}=b_{21}=0$

\section{Hypotheses testing}

(i) No causality-in-variance from $E_{t}$ to $B F_{t}$

$$
H_{0}: a_{12}=b_{12}=0
$$

(ii) No causality-in-variance from $B F_{t}$ to $E_{t}$

$$
H_{0}: a_{21}=b_{21}=0
$$

Notes: $\mathrm{E}_{\mathrm{t}}, \mathrm{EF}_{\mathrm{t}}$, and $\mathrm{BF}_{\mathrm{t}}$ indicate exchange rate changes, net equity flows, and net bond flows, respectively; while $\mathrm{W}$ indicates Wald test statistics. Standard errors, represented in parentheses (.), are calculated using the quasi-maximum likelihood method of Bollerslev and Wooldridge (1992), which is robust to the distribution of the underlying residuals. The superscripts of $\psi$ and $\phi$ parameters denote the lagged time periods, with zero denoting the contemporaneous effect. Insignificant parameters in the conditional mean equation are excluded. $Q(p)$ and $Q^{2}(p)$ are the multivariate Hosking (1981) tests for the $\mathrm{p}^{\text {th }}$ order serial correlation on the standardised residuals $z_{s t}$ and their squares $z_{s t}^{2}$, respectively where $\mathrm{s}=$ 1 (for exchange rate changes $\left(\mathrm{E}_{t}\right)$ ), 2 (for net equity flows $\left(\mathrm{EF}_{\mathrm{t}}\right)$ and net bond flows $\left(\mathrm{BF}_{\mathrm{t}}\right)$ ). P-values are reported in square brackets [.]. The covariance stationarity condition is satisfied by all the estimated models, all the eigenvalues of $\left(\mathrm{A}_{11} \otimes \mathrm{A}_{11}+\mathrm{B}_{11} \otimes \mathrm{B}_{11}\right)$ being less than one in modulus.

${ }^{* * *}$ indicates statistical significance at the $1 \%$ level.

${ }^{* *}$ indicates statistical significance at the $5 \%$ level.

* indicates statistical significance at the $10 \%$ level. 


\section{Table A2}

The estimated bivariate VAR GARCH-BEKK-in-mean model for Canada.

\begin{tabular}{|c|c|c|c|c|c|}
\hline \multicolumn{3}{|c|}{ Panel A. Exchange rates $\left(E_{t}\right)$ and equity flows $\left(E F_{t}\right)$} & \multicolumn{3}{|c|}{ Panel B. Exchange rates $\left(E_{t}\right)$ and bond flows $\left(B F_{t}\right)$} \\
\hline & $E_{t}(s=1)$ & $E F_{t}(s=2)$ & & $E_{t}(s=1)$ & $B F_{t}(s=2)$ \\
\hline \multicolumn{6}{|c|}{ Conditional Mean Equation } \\
\hline$\mu_{\mathrm{s}}$ & $-\underset{(0.097)}{0.034}$ & $\underset{(0.081)}{0.065}$ & $\mu_{s}$ & $-\underset{(0.099)}{0.035}$ & $\begin{array}{l}0.160^{*} \\
(0.084)\end{array}$ \\
\hline$\psi_{2 s}^{(1)}$ & & ${ }^{0.249^{* * *}}$ & $\psi_{1 s}^{(2)}$ & & ${ }_{(0.067)}^{0.136^{*}}$ \\
\hline \multirow[t]{2}{*}{$\psi_{2 s}^{(3)}$} & & $\underbrace{0.143^{* * *}}_{(0.053)}$ & $\psi_{2 s}^{(3)}$ & & ${ }_{(0.070)}^{0.121^{*}}$ \\
\hline & & & $\phi_{2 s}^{(0)}$ & ${ }_{(0.013)}^{0.026^{*}}$ & \\
\hline \multicolumn{6}{|c|}{ Conditional Variance Equation } \\
\hline$C_{1 s}$ & $\underset{(0.164)}{0.060}$ & & $c_{1 s}$ & $\begin{array}{l}0.230^{* *} \\
(0.108)\end{array}$ & \\
\hline$c_{2 s}$ & $1_{(0.224)}^{1.270^{* * *}}$ & $\underset{(3.260)}{0.001}$ & $c_{2 s}$ & $\underset{(0.063)}{0.001}$ & $-\underset{(0.012)}{0.001}$ \\
\hline$a_{1 s}$ & $\underbrace{0.328^{* * *}}_{(0.050)}$ & $-\underset{(0.061)}{0.017}$ & $a_{1 s}$ & $\underbrace{0.314^{* *}}_{(0.047)}$ & $-\underset{(0.031)}{0.070^{* *}}$ \\
\hline$a_{2 s}$ & $-\underset{(0.097)}{0.001}$ & $\begin{array}{l}0.260^{* *} \\
(0.131)\end{array}$ & $a_{2 s}$ & $\underset{(0.038)}{0.001}$ & $-{ }_{(0.036)}^{0.109^{* * *}}$ \\
\hline$b_{1 s}$ & $\underbrace{0.921^{* * *}}_{(0.034)}$ & $-\underset{(0.103)}{0.097}$ & $b_{1 s}$ & ${ }_{(0.018)}^{0.947^{* * *}}$ & $\underbrace{0.017^{* *}}_{(0.008)}$ \\
\hline$b_{2 s}$ & $-\underset{(0.158)}{0.274^{*}}$ & $-\underset{(0.603)}{0.242}$ & $b_{2 s}$ & $\underset{(0.013)}{0.004}$ & $\begin{array}{l}0.989^{* * *} \\
(0.006)\end{array}$ \\
\hline Loglik & -1079.477 & & Loglik & -1075.085 & \\
\hline$Q(6)$ & $16.201[0.880]$ & $Q^{2}(6) \quad 13.294[0.897]$ & $Q(6)$ & $13.329[0.960]$ & $Q^{2}(6) \quad 8.539$ [0.992] \\
\hline$Q(12)$ & $29.301[0.984]$ & $Q^{2}(12) 37.210[0.788]$ & $Q(12)$ & $31.505[0.968]$ & $Q^{2}(12) 30.70[0.948]$ \\
\hline
\end{tabular}

Hypotheses testing

(i) No causality-in-variance from $E_{t}$ to $E F_{t}$

$$
H_{0}: a_{12}=b_{12}=0 \quad W=3.045[0.218]
$$

(ii) No causality-in-variance from $E F_{t}$ to $E_{t}$

$H_{0}: a_{21}=b_{21}=0 \quad W=3.889[0.143] \quad H_{0}: a_{21}=b_{21}=0$

$$
H_{0}: a_{12}=b_{12}=0
$$

Hypotheses testing

(i) No causality-in-variance from $E_{t}$ to $B F_{t}$

(ii) No causality-in-variance from $B F_{t}$ to $E_{t}$

Notes: See notes to Table A1. 


\section{Table A3}

The estimated bivariate VAR GARCH-BEKK-in-mean model for the euro area.

\begin{tabular}{|c|c|c|c|c|c|}
\hline \multicolumn{3}{|c|}{ Panel A. Exchange rates $\left(E_{t}\right)$ and equity flows $\left(E F_{t}\right)$} & \multicolumn{3}{|c|}{ Panel B. Exchange rates $\left(E_{t}\right)$ and bond flows $\left(B F_{t}\right)$} \\
\hline & $E_{t}(s=1)$ & $E F_{t}(s=2)$ & & $E_{t}(s=1)$ & $B F_{t}(s=2)$ \\
\hline \multicolumn{6}{|c|}{ Conditional Mean Equation } \\
\hline$\mu_{s}$ & $-\underset{(0.178)}{0.065}$ & ${ }_{(0.916)}^{1.818^{* *}}$ & $\mu_{\mathrm{s}}$ & $\begin{array}{l}0.023 \\
(0.194)\end{array}$ & $\underbrace{0.627^{* * *}}_{(0.274)}$ \\
\hline$\psi_{1 s}^{(1)}$ & & $\underbrace{0.229^{* *}}_{(0.101)}$ & $\psi_{2 s}^{(1)}$ & & ${ }_{(0.058)}^{0.142^{* *}}$ \\
\hline$\psi_{2 s}^{(2)}$ & & $\begin{array}{l}0.314^{* * *} \\
(0.058)\end{array}$ & $\psi_{2 s}^{(2)}$ & & ${ }_{(0.059)}^{0.171^{* * *}}$ \\
\hline$\psi_{2 s}^{(3)}$ & & $\underbrace{0.129^{* *}}_{(0.057)}$ & $\phi_{2 s}^{(2)}$ & $-\underset{(0.027)}{0.049^{*}}$ & \\
\hline$\phi_{2 s}^{(0)}$ & $-\underset{(0.105)}{0.202^{*}}$ & & & & \\
\hline \multicolumn{6}{|c|}{ Conditional Variance Equation } \\
\hline$c_{1 s}$ & $\underset{(0.113)}{0.480^{* * *}}$ & & $C_{1 s}$ & $\begin{array}{l}0.294 \\
(0.252)\end{array}$ & \\
\hline$c_{2 s}$ & $-\underbrace{0.819^{* * *}}_{(0.069)}$ & $-\underset{(0.071)}{0.001}$ & $C_{2 s}$ & ${ }_{(0.096)}^{0.402^{* * *}}$ & $-\underset{(0.056)}{0.001}$ \\
\hline$a_{1 s}$ & ${ }_{(0.030)}^{0.115^{* * *}}$ & $\begin{array}{l}0.021 \\
(0.027)\end{array}$ & $a_{1 s}$ & ${ }_{(0.066)}^{0.174^{* * *}}$ & $\underset{(0.027)}{0.010}$ \\
\hline$a_{2 s}$ & $\underset{(0.074)}{0.001}$ & ${ }_{(0.073)}^{0.382^{* * *}}$ & $a_{2 s}$ & ${ }_{(0.120)}^{0.313^{* * *}}$ & $-{ }_{(0.067)}^{0.159^{* * *}}$ \\
\hline$b_{1 s}$ & ${ }_{(0.007)}^{0.980^{* * *}}$ & $\begin{array}{l}0.003 \\
(0.007)\end{array}$ & $b_{1 s}$ & ${ }_{(0.020)}^{0.968^{* * *}}$ & $0_{(0.008)}^{0.018^{* * *}}$ \\
\hline$b_{2 s}$ & $\underset{(0.027)}{0.038}$ & ${ }_{(0.030)}^{0.910^{* * *}}$ & $b_{2 s}$ & $-\underbrace{0.134^{* * *}}_{(0.049)}$ & $\underbrace{0.936^{* * *}}_{(0.021)}$ \\
\hline Loglik & -1185.161 & & Loglik & -1193.434 & \\
\hline$Q(6)$ & $20.615[0.661]$ & $Q^{2}(6) \quad 24.614[0.264]$ & $Q(6)$ & $18.292[0.788]$ & $Q^{2}(6) \quad 11.580[0.950]$ \\
\hline$Q(12)$ & $43.803[0.645]$ & $Q^{2}(12) 40.661[0.656]$ & $Q(12)$ & $40.470[0.771]$ & $Q^{2}(12) 40.514[0.662]$ \\
\hline
\end{tabular}

Hypotheses testing

(i) No causality-in-variance from $E_{t}$ to $E F_{t}$

$$
H_{0}: a_{12}=b_{12}=0 \quad W=0.619 \text { [0.448] }
$$

(ii) No causality-in-variance from $E F_{t}$ to $E_{t}$

$$
H_{0}: a_{21}=b_{21}=0
$$

Hypotheses testing

(i) No causality-in-variance from $E_{t}$ to $B F_{t}$

$$
H_{0}: a_{12}=b_{12}=0
$$

(ii) No causality-in-variance from $B F_{t}$ to $E_{t}$

$$
H_{0}: a_{21}=b_{21}=0
$$

$W=20.90[0.000]$

Notes: See notes to Table A1. 


\section{Table A4}

The estimated bivariate VAR GARCH-BEKK-in-mean model for Japan.

\begin{tabular}{|c|c|c|c|c|}
\hline \multicolumn{2}{|c|}{ Panel A. Exchange rates $\left(E_{t}\right)$ and equity flows $\left(E F_{t}\right)$} & \multicolumn{3}{|c|}{ Panel B. Exchange rates $\left(E_{t}\right)$ and bond flows $\left(B F_{t}\right)$} \\
\hline$E_{t}(s=1)$ & $E F_{t}(s=2)$ & & $E_{t}(s=1)$ & $B F_{t}(s=2)$ \\
\hline \multicolumn{5}{|c|}{ Conditional Mean Equation } \\
\hline$\underset{(0.190)}{0.112}$ & $-\underset{(0.082)}{0.199^{* *}}$ & $\mu_{s}$ & $\underset{(0.211)}{0.286}$ & $\underbrace{1.472^{* * *}}_{(0.426)}$ \\
\hline$\underset{(0.062)}{0.100^{*}}$ & & $\psi_{1 s}^{(1)}$ & & $-{ }_{(0.129)}^{0.390^{* * *}}$ \\
\hline$\psi_{2 s}^{(1)}$ & $\underbrace{0.530^{* * *}}_{(0.046)}$ & $\psi_{2 s}^{(1)}$ & $\underbrace{0.077^{* * *}}_{(0.026)}$ & $\underset{(0.073)}{0.126^{*}}$ \\
\hline & & $\psi_{2 s}^{(2)}$ & $\underbrace{0.065^{* * *}}_{(0.020)}$ & $-\underset{(0.046)}{0.084^{*}}$ \\
\hline & & $\psi_{1 s}^{(3)}$ & $\underbrace{0.104^{* *}}_{(0.048)}$ & $\underset{(0.021)}{0.037^{*}}$ \\
\hline & & $\psi_{2 s}^{(3)}$ & $\frac{0.037^{*}}{(0.021)}$ & $\underset{(0.049)}{0.101^{* *}}$ \\
\hline & & $\psi_{1 s}^{(4)}$ & $-\underset{(0.059)}{0.098^{*}}$ & \\
\hline & & $\psi_{1 s}^{(5)}$ & $-\underset{(0.055)}{0.125^{* *}}$ & \\
\hline & & $\phi_{2 s}^{(0)}$ & $-\underset{(0.050)}{0.091^{*}}$ & \\
\hline
\end{tabular}

Conditional Variance Equation

\begin{tabular}{|c|c|c|c|c|c|}
\hline$C_{1 \mathrm{~s}}$ & $\frac{2.192^{* * *}}{(0.300)}$ & & $C_{1 s}$ & $\underbrace{1.600^{* * *}}_{(0.214)}$ & \\
\hline$c_{2 s}$ & $\underset{(0.266)}{0.012}$ & $-\underset{(0.156)}{0.001}$ & $c_{2 s}$ & $-\underset{(0.196)}{0.243}$ & $\underbrace{0.743^{* * *}}_{(0.089)}$ \\
\hline$a_{1 s}$ & ${ }_{(0.098)}^{0.356 * * *}$ & $\begin{array}{l}0.031 \\
(0.032)\end{array}$ & $a_{1 s}$ & ${ }_{(0.073)}^{0.265^{* * *}}$ & $-\underset{(0.032)}{0.047}$ \\
\hline$a_{2 s}$ & $\underset{(0.315)}{0.357}$ & ${ }_{(0.133)}^{0.327^{* *}}$ & $a_{2 s}$ & $-\underset{(0.343)}{0.259}$ & $\underset{(0.229)}{0.528}$ \\
\hline$b_{1 s}$ & $\frac{0.542^{* * *}}{(0.132)}$ & $-{ }_{(0.031)}^{0.231^{* * *}}$ & $b_{1 s}$ & ${ }_{(0.030)}^{0.799^{* * *}}$ & $\underbrace{0.124^{* * *}}_{(0.038)}$ \\
\hline$b_{2 s}$ & $\begin{array}{c}0.624^{*} \\
(0.349)\end{array}$ & $\begin{array}{c}0.753^{* * *} \\
(0.081) \\
\end{array}$ & $b_{2 s}$ & $-\underset{(0.265)}{0.241}$ & $\begin{array}{c}0.439^{*} \\
(0.284)\end{array}$ \\
\hline$\overline{\text { Loglik }}$ & -1195.794 & & Loglik & -1157.405 & \\
\hline$Q(6)$ & $31.611[0.136]$ & $Q^{2}(6) \quad 15.878[0.776]$ & $Q(6)$ & $23.606[0.484]$ & $Q^{2}(6) \quad 12.521[0.924]$ \\
\hline$Q(12)$ & $64.352[0.057]$ & $Q^{2}(12) 28.645$ [0.972] & $Q(12)$ & $57.582[0.161]$ & $Q^{2}(12) 28.743[0.971]$ \\
\hline
\end{tabular}

Hypotheses testing

(i) No causality-in-variance from $E_{t}$ to $E F_{t}$

$$
H_{0}: a_{12}=b_{12}=0 \quad W=55.87 \text { [0.000] }
$$

(ii) No causality-in-variance from $E F_{t}$ to $E_{t}$

$$
H_{0}: a_{21}=b_{21}=0 \quad W=13.53[0.001] \quad H_{0}: a_{21}=b_{21}=0
$$

Notes: See notes to Table A1.
Hypotheses testing

(i) No causality-in-variance from $E_{t}$ to $B F_{t}$ $H_{0}: a_{12}=b_{12}=0$ $W=10.85[0.004]$ (ii) No causality-in-variance from $B F_{t}$ to $E_{t}$ $W=5.955[0.050]$ 


\section{Table A5}

The estimated bivariate VAR GARCH-BEKK-in-mean model for Sweden.

Panel A. Exchange rates $\left(E_{t}\right)$ and equity flows $\left(E F_{t}\right) \quad$ Panel B. Exchange rates $\left(E_{t}\right)$ and bond flows $\left(B F_{t}\right)$

Conditional Mean Equation

$E_{t}(s=1) \quad E F_{t}(s=2) \quad E_{t}(s=1) \quad B F_{t}(s=2)$

$\mu_{\mathrm{s}}$

$\psi_{2 s}^{(1)}$

$\psi_{2 s}^{(2)}$

$\phi_{2 s}^{(5)}$

$$
-\underset{(0.008)}{0.013^{*}}
$$

Conditional Variance Equation

$c_{1 s}$

$$
\begin{aligned}
& 1.128 \\
& (0.810)
\end{aligned}
$$

$c_{2 s}$

$$
-\underset{(0.757)}{0.567}
$$

$a_{1 s}$

$$
{ }_{(0.094)}^{0.502^{* * *}}
$$

$a_{2 s}$

$-0.427^{*}$

$b_{1 s}$

$0_{(0.079)}^{0.740^{* * *}}$

$b_{2 s}$

$0.680^{*}$

$(0.382)$

Loglik -1274.357

$Q(6) \quad 17.970$ [0.804]

$Q(12) 34.809$ [0.922]

(6) $10.660[0.968]$

$1.183^{* * *}$

$(0.421)$

0.023

$0.506^{* *}$

$(0.251)$

0.013

$(0.030)$

$0.382^{* *}$ $(0.185)$

Hypotheses testing

(i) No causality-in-variance from $E_{t}$ to $E F_{t}$

$H_{0}: a_{12}=b_{12}=0$

$$
W=1.163 \text { [0.559] }
$$

(ii) No causality-in-variance from $E F_{t}$ to $E_{t}$

$\begin{array}{cc}\mu_{s} & 0.066 \\ & (0.165) \\ \phi_{2 s}^{(0)} & -\underset{(0.024)}{0.028^{* * *}}\end{array}$

$\underbrace{0.597^{* * *}}_{(0.130)}$

(0.024)

$H_{0}: a_{21}=b_{21}=0$

$W=4.662[0.097]$

$c_{1 s}$

$C_{2 s}$

$a_{1 s}$

$a_{2 s}$

$b_{1 s}$

$b_{1 s} \quad 0_{(0.083)}^{0.792^{* * *}}$

$b_{2 s} \quad-0.445^{* * * *}$

(0.103)

$\begin{array}{lr}\text { Loglik } & -1277.110 \\ Q(6) & 24.507[0.432]\end{array}$

$Q(12) \quad 39.705$ [0.797]

$Q^{2}(6) \quad 16.166[0.760]$

$Q^{2}(12) \quad 37.887$ [0.764]

Hypotheses testing

(i) No causality-in-variance from $E_{t}$ to $B F_{t}$

$H_{0}: a_{12}=b_{12}=0$

$W=0.399[0.819]$

(ii) No causality-in-variance from $B F_{t}$ to $E_{t}$

$H_{0}: a_{21}=b_{21}=0$

$W=36.54[0.000]$

Notes: See notes to Table A1. 


\section{Table A6}

The estimated bivariate VAR GARCH-BEKK-in-mean model for the UK.

Panel A. Exchange rates $\left(E_{t}\right)$ and equity flows $\left(E F_{t}\right) \quad$ Panel B. Exchange rates $\left(E_{t}\right)$ and bond flows $\left(B F_{t}\right)$

Conditional Mean Equation

$E F_{t}(s=2) \quad B E_{t}(s=1) \quad B F_{t}(s=2)$

\begin{tabular}{|c|c|c|c|c|c|}
\hline$\mu_{\mathrm{s}}$ & $-\underset{(0.202)}{0.060}$ & $\underset{(0.139)}{0.239^{*}}$ & $\mu_{s}$ & $-\underset{(0.194)}{0.370^{*}}$ & $\begin{array}{l}1.334^{* * *} \\
(0.185)\end{array}$ \\
\hline$\psi_{2 s}^{(1)}$ & & $\underbrace{0.186^{* * *}}_{(0.054)}$ & $\psi_{1 s}^{(1)}$ & & $\underbrace{0.342^{* *}}_{(0.109)}$ \\
\hline$\psi_{2 s}^{(2)}$ & & $\underset{(0.051)}{0.096^{*}}$ & $\phi_{2 s}^{(2)}$ & $-\underset{(0.025)}{0.052^{* *}}$ & \\
\hline
\end{tabular}

$\psi_{2 s}^{(3)} \quad \begin{aligned} & 0.156^{* * * *} \\ & (0.048)\end{aligned}$

$\phi_{2 s}^{(3)} \quad-\underset{(0.017)}{0.028^{*}}$

Conditional Variance Equation

\begin{tabular}{|c|c|c|c|c|c|}
\hline$C_{1 s}$ & ${ }_{(0.146)}^{0.659^{* * *}}$ & & $c_{1 s}$ & $\underset{(0.160)}{0.290^{*}}$ & \\
\hline$C_{2 s}$ & $-1.133^{* * * *}$ & $\underset{(0.272)}{0.001}$ & $c_{2 s}$ & ${ }_{(0.041)}^{0.173^{* * *}}$ & $\underset{(0.063)}{0.001}$ \\
\hline$a_{1 s}$ & ${ }_{(0.070)}^{0.294^{* * *}}$ & $\underset{(0.040)}{0.032}$ & $a_{1 s}$ & ${ }_{(0.139)}^{0.265^{* *}}$ & ${ }_{(0.040)}^{0.070^{*}}$ \\
\hline$a_{2 s}$ & $-\underset{(0.154)}{0.074}$ & $-{ }_{(0.097)}^{0.226^{* *}}$ & $a_{2 s}$ & $-\underset{(0.067)}{0.039}$ & $-\underset{(0.036)}{0.001}$ \\
\hline$b_{1 s}$ & ${ }_{(0.027)}^{0.899^{* * *}}$ & $\underset{(0.040)}{0.023}$ & $b_{1 s}$ & $\begin{array}{l}0.968^{* * *} \\
(0.038)\end{array}$ & $-{ }_{(0.009)}^{0.066^{* * *}}$ \\
\hline$b_{2 s}$ & $\underbrace{0.502^{* * *}}_{(0.056)}$ & $\begin{array}{l}0.468^{* * *} \\
(0.003)\end{array}$ & $b_{2 s}$ & $\begin{array}{c}0.324^{* * *} \\
(0.088)\end{array}$ & $\begin{array}{l}0.922^{* * *} \\
(0.022)\end{array}$ \\
\hline$\overline{\text { Loglik }}$ & -1172.155 & & Loglik & -1078.105 & \\
\hline$Q(6)$ & $16.962[0.850]$ & $Q^{2}(6) \quad 8.996[0.989]$ & $Q(6)$ & $21.022[0.637]$ & $Q^{2}(6) \quad 27.405[0.157]$ \\
\hline$Q(12)$ & $40.318[0.776]$ & $Q^{2}(12) 24.90[0.993]$ & $Q(12)$ & 38.397 [0.837] & $Q^{2}(12) 39.612$ [0.698] \\
\hline
\end{tabular}

Hypotheses testing

(i) No causality-in-variance from $E_{t}$ to $E F_{t}$

$$
H_{0}: a_{12}=b_{12}=0 \quad W=1.413 \text { [0.493] }
$$

(ii) No causality-in-variance from $E F_{t}$ to $E_{t}$

$$
H_{0}: a_{21}=b_{21}=0
$$

Hypotheses testing

(i) No causality-in-variance from $E_{t}$ to $B F_{t}$ $H_{0}: a_{12}=b_{12}=0$ $W=59.62[0.000]$

(ii) No causality-in-variance from $B F_{t}$ to $E_{t}$ $H_{0}: a_{21}=b_{21}=0$ $W=12.83[0.001]$

Notes: See notes to Table A1. 